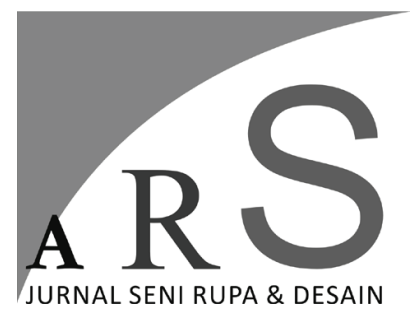

Volume 23 Nomor 2 Mei - Agustus 2020

\section{KAJIAN VISUAL KEMASAN TEH TUBRUK LOKAL}

\author{
Ayu Latifah
}

Program Studi Desain Komunikasi Visual

Jurusan Desain, Fakultas Seni Rupa

ISI Yogyakarta

Jl. Parangtritis, Km 6.5, Sewon, Bantul, Yogyakarta

E-mail: ayuallatif@gmail.com

\begin{abstract}
ABSTRAK
Penelitian ini mengkaji visual kemasan dalam teh Cap Nyapu dan teh Cap Soklat. Kedua produk teh lokal tersebut dikaji guna mengetahui apakah makna visual yang terdapat dalam visual kemasan teh Cap Nyapu dan teh Cap Soklat, dan apakah makna visual tersebut memiliki kaitannya dengan latar belakang sosial didalamnya. Penelitian ini menggunakan metode penelitian deskriptif dengan pendekatan kualitatif dengan menggunakan teknik pengumpulan data studi pustaka, observasi, dan wawancara/ interview. Dalam penelitian ini, pengaplikasian teori kepada objek yang dikaji hanya menggunakan salah satu dari teori metode visual Gillian Rose yaitu site of image itself. Hasil penelitian menunjukkan bahwa berdasarkan prinsip-prinsip desain, visual kemasan teh Cap nyapu memiliki gaya Victorian sedangkan visual kemasan teh Cap Soklat menunjukkan gaya Art Deco. Ilustrasi dalam visual kemasan teh Cap Nyapu, lekat dengan kebudayan Jawa dan menunjukkan tren kala itu, dimana perempuan masih mengenakan kebaya dan batik dalam kehidupan sehari-hari yaitu masa kolonialisme. Sementara dalam visual kemasan teh Cap Soklat menampilkan ilustrasi buah kakao, merupakan tanaman yang masuk dalam kategori tanaman cuulturstelsel.
\end{abstract}

Kata kunci: desain kemasan, teh tubruk, kajian visual, makna visual.

\begin{abstract}
Visual Packaging Of Local Powder Tea. The results showed that based on the principles of design, typography in the two samples used a lot of sans serif type typography that impressed dynamic and informal. The illustrations contained in the packaging of Cap Nyapu tea and Cap Soklat tea often use manual drawing techniques, but with different design styles. The visual of the packaging tea stamp has a Victorian style while the visual packaging of tea stamp Soklat shows the Art Deco style. Illustration in the visual packaging of the tea cap Nyapu, closely with Javanese culture and shows the trend at that time, where women still wear kebaya and batik in everyday life, namely the colonialism period. While in the visual packaging of tea packaging Cap Soklat displays illustrations of cocoa fruit. From the sociohistorical background, the two plants, namely tea and cocoa, are included in the category of plants grown in the cuulturstelsel system.
\end{abstract}

Keywords: visual packaging, brew tea, visual study, visual meaning 


\section{Pendahuluan}

Sebagaimana pada barang industri lainnya, industri teh juga memerlukan kemasan untuk produk yang akan didistribusikan dan dipasarkan. Desain kemasan sudah mendapatkan peran pentingnya sebagai media komunikasi visual sejak VOC menerapkan politik merkantilisme di Nusantara Desain kemasan sebagai bagian dari desain komunikasi visual, tidak hanya mempunyai fungsi estetik dan menarik konsumen namun juga mampu menyajikan informasi didalamnya.

Dua dari sekian banyaknya merk teh tubruk yang berada dipasaran adalah teh Cap Nyapu dan teh Cap Soklat. Teh Cap Nyapu diproduksi oleh Perusahaan Teh Widodo sebagaimana tertera dalam kemasannya (yang telah berganti menjadi CV. Panen Lestari) yang terletak di Jl. Jend. A. Yani, Pekalongan, Jawa Tengah. Sementara itu, teh Cap Soklat merupakan teh tubruk yang diproduksi oleh PT. Kartini Teh Nusantara yang terletak di Batang, Jawa Tengah. Kedua produk teh lokal tersebut dikaji guna mengetahui apakah makna visual yang terdapat dalam visual kemasan teh Cap Nyapu dan teh Cap Soklat, dan apakah makna visual tersebut memiliki kaitannya dengan latar belakang sosial pada visual kemasan teh Cap Nyapu dan teh Cap Soklat.

\section{Pembahasan \\ Desain Kemasan}

Desain kemasan telah memegang peranan yang penting sejak kemasan diciptakan. Kemasan pun sudah menjadi kebutuhan dan menjadi naluri manusia untuk memenuhi kebutuhannya. Seperti halnya pada masa sebelum plastik ditemukan, manusia purba menggunakan daun, serabut kelapa dan berbagai bahan alam lainnya untuk menngemas makanan maupun minuman. Seiring dengan ditemukannya kertas dan berkembangnya teknik mencetak, desain yang digunakan dalam kemasan pun kemudian memulai perannya yang tidak kalah penting. Menurut Julianti (2014:9) sejarah kemasan di Indonesia tidak jauh berbeda perkembangannya dengan sejarah kemasan di dunia. Bahan kemasan yang umum digunakan di Nusantara adalah daun, kayu, bambu, gerabah, kertas, kaca, gelas dan kaleng.

\section{Desain Kemasan Sebagai Alat Komunikasi}

Desain Kemasan menjadi bagian dari komunikasi visual tidak hanya terkait dengan fungsi namun juga dari pengertian desain itu sendiri. Desain tidak sama halnya dengan lukisan yang hanya menjadi sarana berekspresi bagi seniman, namun desain lebih diprioritaskan sebagai sarana informasi dan komunikasi daripada fungsi estetiknya saja. Desain kemasan harus berfungsi sebagai sarana estetika untuk berkomunikasi dengan semua orang dari berbagai latar belakang, minat dan pekerjaan yang berbeda, karena itu pengetahuan tentang antropologi, sosiologi, psikologi, etnografi dapat memberikan manfaat dalam proses desain dengan pilihan desain yang tepat. Khususnya pengetahuan terhadap keragaman sosial dan budaya, perilaku manusia secara nonbiologis dan selera kebudayaan serta perbedaan budaya dapat membantu memahami bagaimana elemen visual dapat menjalankan fungsinya. (Klimchuk \& Krasovec, 2007)

\section{Desain Kemasan sebagai Alat Identifikasi dalam Pemasaran}

Sebagai suatu komponen masyarakat, konsumerisme terus berlanjut seiring dengan banyaknya ragam produk dan jasa yang terus bertumbuh hingga saat ini. Terdapat produk yang berbeda-beda yang berderet di rak department store, toko grosir, swalayan, outlet dan internet dan dalam hal ini produk lebih ditonjolkan dengan desain kemasannya.

Sebagaimana menurut Klimchuk \& Krasovec (2007:35) produk telah menyatu kedalam semua aspek kehidupan kita sehingga produk bukan lagi merupakan barang kebutuhan tetapi keinginan. Dengan banyaknya pilihan konsumen maka muncullah kompetisi produk. Kompetisi pada akhirnya mendorong kebutuhan untuk diferensiasi pasar dan kebutuhan untuk berbeda dari pasaran.

\section{Desain Kemasan dan Masyarakat}

Desain kemasan memegang perannya dalam masyarakat terkait dengan nilai-nilai budaya yang terkandung didalamnya, seperti tren, seni, etnis dan sebagainya. Dalam beberapa 
hal, salah satu tujuan khusus dari desain kemasan adalah untuk merepresentasikan nilai-nilai budaya tersebut. Seperti yang diungkapkan oleh Klimchuk \& Krasovec (2007:46) oleh karena keberadaan desain kemasan utamanya adalah dipasar (supermarket, outlet penjualan grosir atau department store) dimana orang-orang dengan berbagai latar belakang budaya dan nilai berkumpul, desain kemasan harus mampu menarik perhatian konsumen dengan segera. Hal ini dicapai dengan menerapkan elemen visual dan desain yang menarik target konsumen.

\section{Desain Kemasan dan Merk}

Secara visual, desain kemasan dapat mengekspresikan suatu merk, yang dapat berupa kualitas, nilai, estetika maupun kinerja dari merk suatu produk tertentu. Misalnya tipografi yang sukar dibaca atau tidak mengkomunikasikan suatu produk tentunya akan sangat berpengaruh dalam penilain konsumen pada merk produk tersebut. Dari perspektif desain kemasan, merk didefinisikan oleh kehadirannya dalam masyarakat konsumen, oleh atribut fisik produk dan konotasi emosional dan oleh bagaimana merk itu berkaitan dengan aspirasi konsumen. Merk menjadi sarana bagi sebuah perusahaan untuk membedakan dirinya sendiri dalam pikiran konsumen. (Klimchuk \& Krasovec, 2007:38) Sementara itu, agar dapat dikatakan berhasil, maka penampilan kemasan berbasis budaya tetap harus mempunyai daya tarik. Daya tarik kemasan menurut Wirya (1999: 12-15) dalam buku "Kemasan yang Menjual", kemasan dapat digolongkan menjadi dua, yaitu sebagai berikut:

1. Daya Tarik Visual (Estetika)

Daya tarik visual mengacu pada penampilan kemasan atau label suatu produk, yang mencakup warna, bentuk, merk, ilustrasi, teks, serta tata letak. Seluruhnya dikombinasikan untuk menciptakan suatu kesan menyeluruh untuk memberikan mutu daya tarik visual secara optimal. Daya tarik visual inilah sebuah citra dapat dibangun dan selanjutnya dikuatkan oleh kualitas produk.
2. Daya Tarik Praktis (Fungsional)

Daya tarik praktis merupakan efektivitas dan efisiensi suatu kemasan yang ditujukan konsumen maupun distributor. Misal untuk kemudahan penyimpanan atau pemajangan produk.

\section{Gaya Desain \\ Art Nouveau (1890-1920)}

Desainer Art Nouveau mendukung perlunya sensitivitas estetik pada penampilan benda pakai dan sensibilitas penggunaan material dan penggarapan aspek fungsionalnya. Mereka memperlihatkan, bahwa suatu pakai bisa fungsional sekaligus indah dan mengekspresikan imajinasi perancangnya secara utuh. Suatu benda dapat menjadi pernyataan estetik. Akan tetapi, berbeda dengan para pelopor Arts and Crafts, para seniman dan desainer Art Nouveau lebih realistis menyambut modernisasi dan tidak mencoba mencari 'keindahan' melalui semangat Historikisme Abad Pertengahan. (Sunarto, 2013: 57) Art Nouveau populer di Eropa Barat dan Amerika dari sekitar tahun 1890 sampai 1920, ditandai dengan ornamen garis dan kurva yang rumit dibuat dengan palette warna yang cerah dan enak dipandang. Perbedaan Art Deco dan Art Nouveau yaitu Art Nouveau identik dengan gambar tangan/manual dan menggunakan garis serta bentuk yang alami, sedangkan Art Deco menggunakan bentuk yang geometrid dan gradasi warna yang lebih modern.

Salah satu ciri utama dari gaya Art Nouveau adalah digambar tangan atau hand drawing, penggunaan ornamen garis dan kurva yang alami serta penggunaan objek wanita pada desain. Art Nouveau merupakan gaya desain internasional pertama yang berkembang tahun 1880-an hingga era awal perang dunia pertama walaupun hanya berlangsung relatif singkat. Desain Art Nouveau umumnya terinspirasi dari bentuk-bentuk alam seperti bunga, burung, serangga, ombak laut, penggunaan objek wanita dan sebagainya. gaya Art Nouveau biasanya ditandai dengan adanya ornamen yang meliukliuk mengikuti irama alam dan lingkungan. 


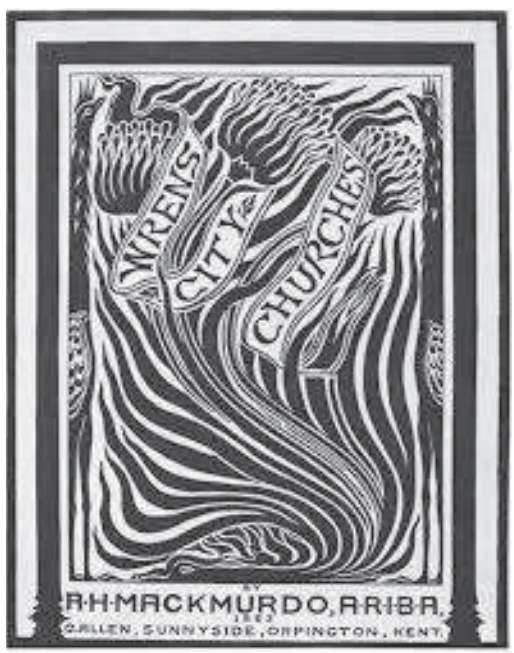

Gambar 2. A.H.MC. MURDO, Sampul muka buku 'Wren City Church', 1883.

\section{Art Deco (1925-1940)}

Pada tahun 1912, pemerintah Prancis setuju untuk mensponsori pameran internasional seni dekoratif, mempromosikan dominasi Prancis di bidang desain industri. Pameran yang dijadwalkan 1915 itu ditunda karena Perang Dunia I kemudian diselenggarakan di Paris antara bulan April dan Oktober 1925, "Internationale des Arts Décoratifs et Industriels Modernes" (International Exhibition of Modern Decorative and Industrial Arts), dikhususkan untuk seni desain yang menarik lebih dari 16 juta pengunjung. Persyaratan utama untuk dimasukkan (lebih dari dua puluh negara diundang untuk berpartisipasi) adalah bahwa semua karya harus benar-benar modern; tidak ada salinan gaya sejarah masa lalu yang diizinkan. Pameran inilah yang kemudian menjadi asal-usul istilah pada gaya yang sekarang dikenal sebagai Art Deco. Sejak saat itulah, Art Deco telah mencakup banyak dan beragam bentuk desain yang berkembang hingga awal Perang Dunia II. (Graphic Design History vis $\neg$ ualartsdepartment.wordpress.com)

Gaya 'Art Deco' dalam desain grafis mengembalikan lagi 'Dekorativisme' tetapi tidak harus dalam bentuk ornamen. Kesan dekoratif bisa dicapai melalui permainan elemen geometrik, blok tipografi, tekstur dan nuansa warna. Gaya ini mengolah teknik stilasi dan permainan garis, bidang dan warna yang teratur dan sensitif. Hurufhuruf 'Art Deco' unik dan segar, serta dibuat dengan apik dan sensitif. Secara keseluruhan gaya ini mengekspresikan suatu penampilan dan kesan yang elegan dan berkelas. (Sunarto, 2013:96)

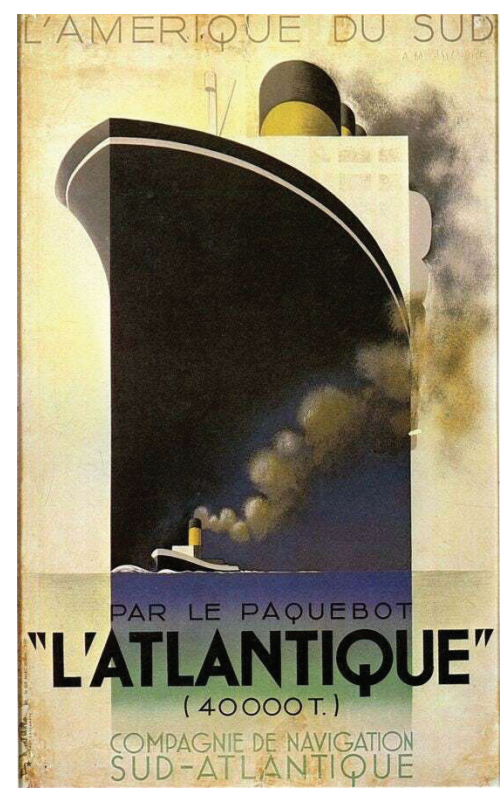

Gambar 2. A.M. Cassandre, "L’Atlantique” poster (sumber: https://visualartsdepartment.wordpress.com/ deco)

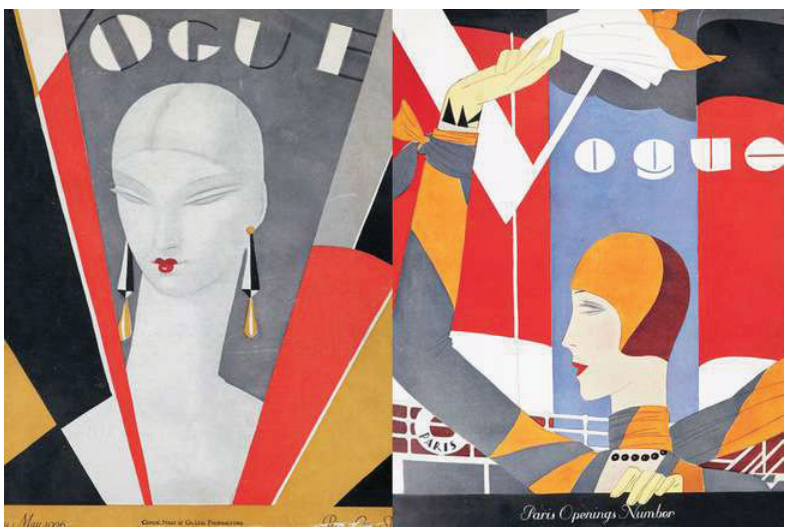

Gambar 3. French Art Deco ; Eduardo Benito, Vogue Cover, 1927 (Sumber: Heller, Steven dan Chwast Seymor: 1988 dalam Sunarto: 2013)

\section{Konstruksi Visual}

\section{Sosiologi Desain}

Sosiologi desain tumbuh dan berkembang dipicu oleh semakin kompleksnya permasalahan desain dan kehidupan manusia. Kedekatan desain dengan manusia itulah yang menjadi objek kajian yang tidak ada habisnya. Dalam kacamata sosiologi, manusia diamati secara empiris melalui pengamatan gejala dan pengelompokkan rasnya. Sedangkan dalam kajian sosiologi desain, manusia dapat diamati perilaku kreatifnya, perilaku dekstruktifnya, pembentukan nilai-nilai baru ataupun tumbuhnya akar-akar kebudayaan baru. (Sachari, 2002:10)

Menurut Sachari (2002) sosiologi desain merupakan suatu ilmu yang mempelajari 
perilaku individu, sekelompok orang atau masyarakat yang dipengaruhi oleh karya desain tertentu atau sebaliknya, yaitu karya-karya desain yang menciptakan situasi sosial tertentu dengan pendekatan-pendekatan secara komprehensif.

Dari segi komunikasi, desain dapat mengkomunikasikan pelbagai hal, baik sebagai ekspresi masyarakat tertentu yang berkaitan dengan gaya hidupnya, pendalaman kebudayaan sebuah bangsa ataupun sebagai komunikasi praktis non-verbal. Sedangkan dari segi ekonomi, desain dapat berperan sebagai peningkat kualitas produk ataupun upaya penyelaras cita rasa dengan penggunaannya. Dari segi budaya, desain dapat pula merupakan wujud 'memanusiakan' benda pakai agar memiliki kepatutan dalam lingkungan hubungan sosial, disamping juga sebagai tandatanda keadaban artifak yang dibuat pada kurun waktu tertentu. (Sachari, 2002: 105)

\section{Budaya Visual}

Menurut Sachari dalam Budaya Visual Indonesia (2007), budaya visual adalah tatanan wujud kebudayaan konsep (nilai) dan kebudayaan materi (benda) yang dapat segera ditangkap oleh indera visual (mata) dan dapat dipahami sebagai model pikiran manusia untuk meningkatkan kualitas hidupnya. Dalam konteks budaya visual, istilah desain dapat dipahami sebagai suatu aktivitas dan karya budaya yang teraga dan memiliki makna bagi perkembangan peradaban masyarakatnya. Desain melingkupi semua hal yang berkaitan dengan budaya benda, nilai-nilai dan substansi filosofis yang melatarbelakanginya. (Sachari, 2007: 4)

\section{Metode Visual Gillian Rose}

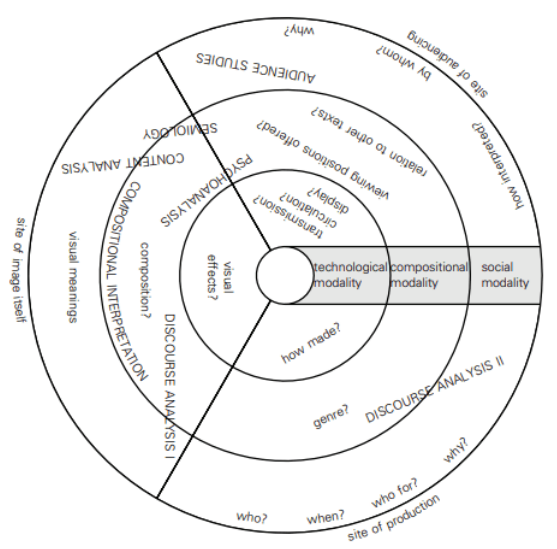

Gambar 4. Sites, Modalities and Methods for Interpreting Visual Materials. (Sumber: Rose, 2002:30)
Menurut Gillian Rose (2002) dalam bukunya Visual Methodologies, ada tiga area yang dapat dilakukan dalam interpretasi visual. Area ini menggambarkan dari sudut pandang mana atau posisi mana yang akan diambil peneliti ketika melakukan interpretasi visual atau memperlakukan objek visual yang sedang dialaminya, yaitu: (1) site of production of an image, (2) site of image itself, (3) site where it is seen by various audiences. Situs pertama berbicara dari sisi proses produksi dibalik materi visual, situs kedua berbicara mengenai materi visual yang tampak dan merupakan hasil produksi. Sedangkan situs ketiga, berbicara dari bagaimana audiens memaknai materi visual tersbeut. Ketiga ranah tersebut saling berkaitan dalam memaknai materi visual dan merupakan penelitian besar dalam metode untuk mengkaji visual. Ketiga ranah tersebut diikat dalam 3 modalitas yaitu teknologi, komposisi dan makna visual seperti yang tertera pada tabel dberikut ini:

Tabel 1. Tabel modalitas area site of images itself

\begin{tabular}{|l|l|l|}
\hline No & Modalitas & Site of image itself \\
\hline 1 & Teknologi & Efek visual \\
\hline 2 & Komposisi & Interpretasi komposisi ruang \\
\hline 3 & $\begin{array}{l}\text { Makna } \\
\text { Sosial }\end{array}$ & Makna Sosial \\
\hline
\end{tabular}

Metode Penelitian Kajian Media dan Budaya. (Sumber: Rachma Ida, 2011)

Penelitian ini mengkhususkan pada site of image itself dengan modalitas seperti pada tabel. Berdasarkan tabel tersebut secara singkatnya dijabarkan sebagai berikut, seperti yang dipaparkan oleh Rose (2002:17)

a. Teknologi

Mirzoeff dalam Rose (2001:17) mendefinisikan teknologi visual sebagai segala bentuk peralatan yang dirancang baik untuk dilihat atau untuk meningkatkan visi alami dan visual dari foto, lukisan cat minyak, komik, televisi, dll.

b. Komposisi

Ketika sebuah gambar dibuat, gambar itu didasarkan pada sejumlah strategi formal: konten, warna dan organisasi spasial, misalnya.

c. Sosial

Istilah singkat ini dimaksudkan untuk merujuk pada berbagai hubungan ekonomi, sosial dan politik, institusi dan praktik-praktik yang terkandung dalam gambar dan melalui hal 
tersebut gambar dapat dilihat dan digunakan sesuai dengan tujuannya. Untuk mengetahui makna yang terkandung dalam suatu gambar visual bisa dilihat secara eksplisit atau implisit, kemudian dapat dirasakan sebagai kebenaran, ilmu pengetahuan ataupun logika umum.

Makna tersebut dibawa melalui pembicaraan sehari-hari, kondisi sosial, seni tinggi, media komunikasi massa dan kelompok yang berbeda dalam masyarakat, lalu dimaknai melalui cara yang berbeda satu dengan yang lainnya sehingga memunculkan opini yang tumbuh dalam masyarakat.

\section{The production of the image}

Interpretasi komposisi adalah cara yang sangat khusus dalam memandang gambar. Ini berfokus paling kuat pada gambar itu sendiri (site of image itself) yang juga memberikan perhatian pada proses produksinya. Biasanya sebuah catatan dibuat dari aspek modalitas sosial dari produksinya: siapa yang menugaskannya, mengapa, siapa yang melukisnya, dan apa yang kemudian terjadi padanya sebelum berakhir di lokasi saat ini (berbagai pemilik dan lokasi lukisan diketahui sebagai asalnya). (Rose, 2002: 37)

Teknologi yang digunakan dalam pembuatan gambar menentukan bentuk, makna dan efeknya. Setiap gambar dapat menghasilkan efek tersendiri setelah melalui proses produksi. Beberapa orang akan berargumen, contohnya kualitas gambar fotografi tertentu membuat kita memahami teknologi apa yang sedang digunakan seorang fotografer setelah melihat hasil karyanya. Kualitas-kualitas dari hasil gambar membentuk modalitas sosial dimana hal tersebut ditampilkan.

Penting untuk mengetahui materi dan teknik apa yang dibuat gambar karena hal itu dapat mempengaruhi dampak yang dimiliki gambar. Joshua Taylor (1957) dalam Rose (2002: 38) memberikan beberapa diskusi yang sangat berguna tentang berbagai teknologi yang telah digunakan untuk menghasilkan gambar bergambar. Ia mengeksplorasi kualitas-kualitas khusus dari media tertentu - menggambar, melukis, seni grafis, patung dan arsitektur \pm dan berbagai cara penggunaannya.

Pembahasannya tentang melukis, misalnya, meneliti berbagai teknik fresco, cat air, tempera, minyak, encaustic dan kolase. James Monaco (2000) meneliti teknologi dengan memindahkan gambar dengan detail serupa. Namun, seperti yang dicatat oleh Taylor (1957: 70), satu-satunya alasan untuk memberi banyak perhatian pada teknologi produksi gambar adalah ketika pengetahuan tentang teknik ini membantu dalam menggambarkan karakteristik tertentu dari karya tersebut. (Rose, 2002: 38)

\section{The image itself}

Pengertian komposisi mengacu pada semua elemen yang digunakan dalam kombinasi. Ketika suatu gambar dibuat, gambar itu menarik sejumlah strategi formal: konten, warna dan organisasi spasial misalnya.

\section{The Good Eye}

Melihat gambar atau mengkaji objek visual menggunakan interpretasi komposisi yang didasarkan pada 5 komponen dengan 3 komponen utama sesuai urutannya yaitu; konten, warna, organisasi spasial, cahaya dan konten ekspresif.

\section{Konten}

Berkaitan dengan isi dari sebuah objek visual. Proses tersebut dapat dilakukan dengan cara mengambil potongan gambar pada objek visual bergerak untuk kemudian dilakukan proses analisis. Saat melihat gambar berdasarkan site of image itself, titik awal dapat menjadi konten gambar tersebut. Apa yang sebenarnya ditunjukkan oleh gambar tersebut? Pertanyaan ini mungkin terkesan sepele dan untuk beberapa gambar memang akan menjadi pertanyaan yang sangat sederhana. Namun tidak untuk beberapa gambar tertentu yang membutuhkan observasi yang lebih seksama. Seperti yang diungkapkan oleh Acton (1997) dalam Rose (2002:39) Beberapa gambar menggambarkan tema atau peristiwa keagamaan, sejarah, mitologis, moral atau sastra atau pada kejadian tertentu yang dapat memecahkan suatu simbol visual yang merujuk kepada tema atau acara pada gambar tersebut.

\section{Warna}

Warna adalah komponen penting lainnya dari komposisi suatu gambar. Lebih jelasnya, Taylor (1957) dalam Rose (2002:39) mendeskripsikan tiga cara untuk menggambarkan warna-warna lukisan: 
a. Rona (Hue)

Mengacu pada warna aktual dalam sebuah lukisan. Dengan demikian warna dominan yang digunakan dalam potret Rembrandt yang direproduksi untuk ulasan Searle adalah cokelat, biru, dan hitam.

b. Saturasi (Saturation)

Saturasi mengacu pada kemurnian warna dalam kaitannya dengan penampilannya dalam spektrum warna. Jadi saturasi tinggi jika suatu warna digunakan dalam bentuk warna yang jelas, dan rendah jika hampir netral.

c. Nilai (Value)

Nilai mengacu pada terang atau gelapnya suatu warna. Jika suatu warna dalam bentuk hampir putih, maka nilainya tinggi; jika dalam bentuk hampir hitam, nilainya rendah. Istilah-istilah tersebut dapat menggambarkan warna yang digunakan dalam sebuah lukisan yang juga diperlukan untuk menggambarkan efek warna dalam suatu gambar. Warna dapat digunakan untuk menekankan elemenelemen tertentu dari suatu gambar, misalnya. Ada juga pertanyaan tentang seberapa serasi kombinasi warnanya dari sebuah lukisan.

\section{The site where it is seen}

Merupakan situs terakhir di mana makna dan efek dari suatu gambar dibuat, karena kita adalah penonton/pengamat dari foto itu dan, seperti semua audiens dengan masingmasing caranya tersendiri melihat dengan jenis pengetahuan yang beragam. John Fiske (1994) menyarankan bahwa ini adalah situs yang paling penting di mana makna gambar dibuat, dan menggunakan istilah audiensi untuk merujuk pada proses di mana gambar visual memiliki makna yang dapat dinegosiasikan atau bahkan ditolak oleh khalayak tertentu yang mengamati dalam keadaan tertentu.

Sosial mungkin merupakan modalitas terpenting untuk memahami audiensi gambar. Praktik sosial yang menyusun tampilan gambar tertentu pada bagian tertentu. Terdapat beberapa penelitian yang telah mengeksplorasi bagaimana audiens yang berbeda menafsirkan gambar visual yang sama dengan cara yang sangat berbeda, dan perbedaan ini telah dikaitkan dengan identitas sosial yang berbeda dari penonton yang bersangkutan.
Terdapat dua aspek dari modalitas sosial audiensi: praktik sosial dari menyaksikan dan identitas sosial dari penonton/pengamat. Akan tetapi, beberapa karya juga menggabungkan kedua aspek audiensi ini.

\section{Sampel}

Pada penelitian ini, terdapat dua jumlah sampel. Dari data yang ada, diambil dua sampel yang dianggap menarik untuk dikaji visual kemasannya dan dinilai memiliki unsur sosiohistoris yang kuat yaitu teh Cap Nyapu dan teh Cap Soklat. Teh Cap Nyapu hanya memproduksi jenis teh tubruk saja dengan satu varian sehingga hanya terdapat satu jenis desain kemasan yang sama dan begitu pula dengan teh cap Soklat. Sehingga sampel dari penelitian ini adalah desain kemasan teh Cap Nyapu dan teh Cap Soklat.
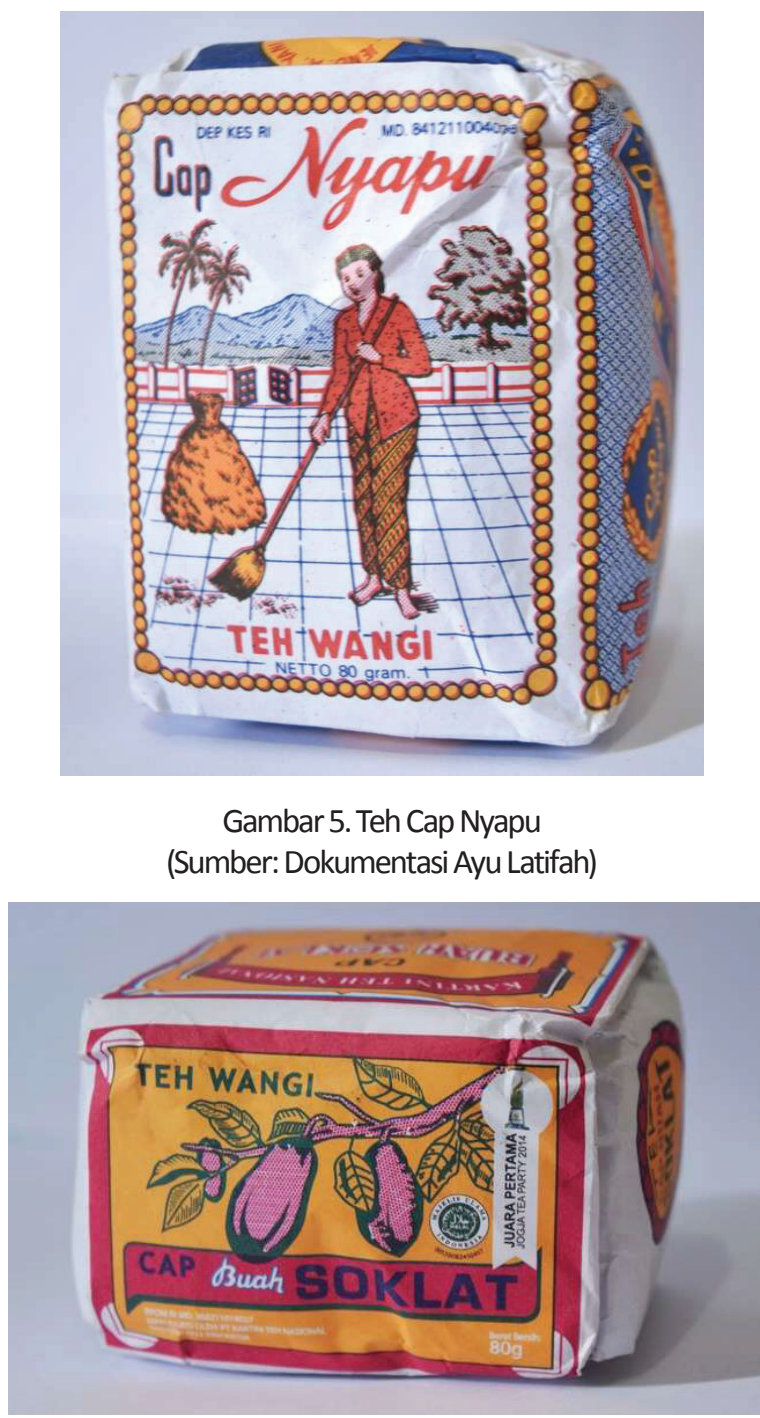

Gambar 6. Teh Cap Soklat (Sumber: Dokumentasi Ayu Latifah) 


\section{Analisis Sampel Teh Cap Nyapu}

Teh Cap Nyapu diproduksi oleh CV. Panen Lestari, Pekalongan yang dulunya bernama Perusahaan Teh Widodo, sebagaimana yang telah dicantukan dalam kemasan sisi kanan visual kemasan teh Cap Nyapu. Pada bagian depan kemasan teh Cap Nyapu menampilkan ilustrasi seorang perempuan berkebaya merah dan jarik bermotif batik yang tengah menyapu remahan gabah. Terlihat dari adanya objek gabah yang barada di sisi kanan perempuan tersebut. Latar belakang ilustrasi tersebut menampilkan pemandangan pegunungan dan hijaunya sawah serta dua pohon sawit dan sebuah pohon yang rimbun. Secara lebih jelasnya akan dipaparkan melalui tahapan sebagai berikut:

\section{Teknologi Visual}

Perkembangan teknologi mempunyai pengaruh yang cukup besar dalam beberapa hal. Namun rupanya hal tersebut tidak berlaku terhadap gaya visualisasi yang digunakan dalam visual kemasan teh Cap Nyapu. Teh Cap Nyapu menggunakan ilustrasi dan komponen-komponen desain yang sama hingga saat ini. Terlepas dari hal tersebut, teknologi visual memiliki kaitannya dengan bentuk, makna, dan efek visualnya. Visual kemasan teh cap Nyapu menggunakan teknik ilustrasi manual yang kemudian dicetak menggunakan teknik offset. Terlihat dari gambar yang ditampilkan seperti sebagaimana tampilan 'realita' dalam kehidupan seharihari. Gambar realis merepresentasikan bentuk dari manusia dalam kehidupan nyata, yang membedakan adalah gambar bersifat dua dimensi, lebih kecil, dan tidak bergerak. Terdapat beberapa efek visual dalam visual kemasan teh Cap Nyapu yaitu:

\section{a. Half-tone}

Gelap terangnya suatu gambar dipengaruhi oleh penentuan arah datangnya cahaya. Bagian yang terkena cahaya akan tampak terang atau berwarna lebih muda. Sementara bagian yang tidak terkena cahaya akan tampak lebih gelap. Half-tone diterapkan untuk menghasilkan gambar agar terlihat realis.

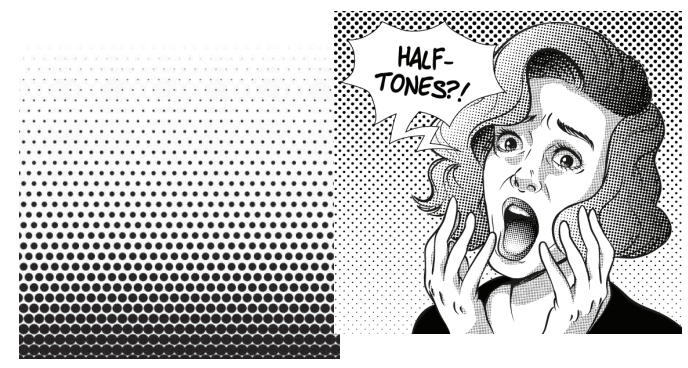

Gambar 7. Halftone

(Sumber: https://www.freepik.com/)

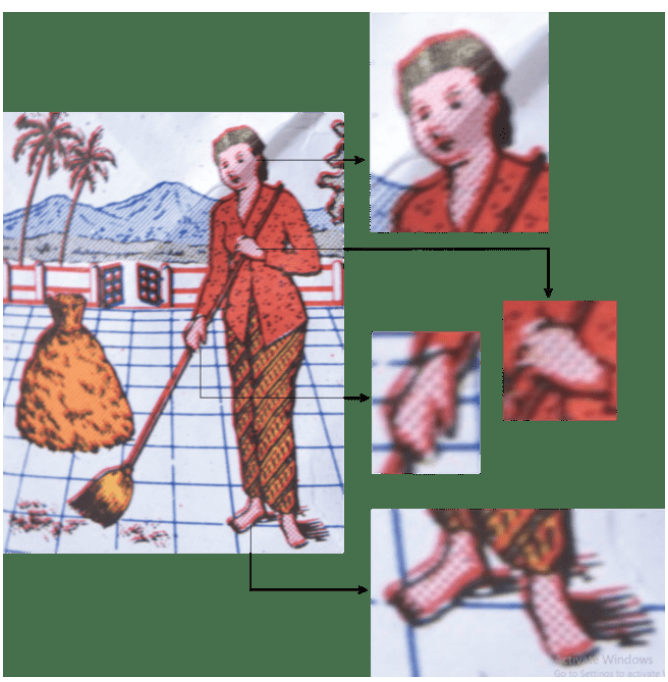

Gambar 8. Half-tone dalam visual kemasan teh Cap Nyapu yang terdapat pada wajah dan tubuh perempuan yang sedang menyapu.

(Sumber: Dokumentasi Ayu latifah)

Half-tone yang tampak pada bagian wajah dan tubuh perempuan yang sedang menyapu yaitu wajah, leher, tangan kanan dan kiri dan kedua kaki. Efek half-tone juga terlihat pada ilustrasi gabah dan pegunungan, padang rumput dan juga pohon. Seperti gambar dibawah ini

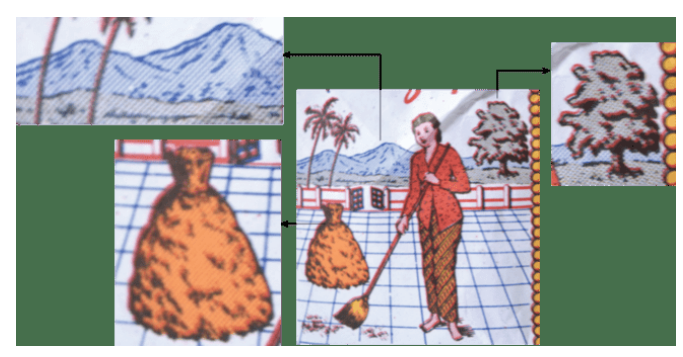

Gambar 9. Half-tone dalam visual kemasan teh Cap Nyapu yang terdapat pada pegunungan, sawah yang terlihat dari jauh seperti padang rumput dan pohon.

(Sumber: Dokumentasi Ayu Latifah) 
Pada bagian pohon, half-tone dalam artian gelap terang sangat kentara dimana sisi gelap dan terang pada pohon mengesankan efek realis dan tiga dimensi atau bervolume. Sementara itu, pada bagian bawah pohon juga tampak sebuah bayangan hitam, yaitu bayangan yang dihasilkan oleh benda itu sendiri. Benda yang terkena sinar akan menghasilkan bayang-bayang. Bayang-bayang itu jatuh tidak jauh dari benda yang terkena cahaya. Dalam menggambar bentuk, peranan baying-bayang akan menentukan terciptanya kesan tiga dimensi atau realis. Oleh Karena itu, bayang-bayang meskipun agak samar-samar tetap harus ada. Bayangan juga terdapat pada perempuan, yaitu terletak di sisi kiri kaki perempuan.

\section{b. Penggunaan Motif}

Motif atau corak dapat mengidentifikasikan suatu gambar. Motif pada gambar biasanya merujuk pada suatu gambar yang sama dan konsisten jaraknya antara satu gambar dengan gambar yang lain sehingga membentuk suatu pola. Dalam visual kemasan teh Cap Nyapu, terdapat tiga macam motif yang berbedabeda, yaitu motif tiga titik yang terdapat pada kebaya merah perempuan yang sedang menyapu. Kemudian motif batik yang terdapat pada jarik sang perempuan. Yang ketiga ialah motif yang menjadi latar belakang (background) pada sisi kanan dan kiri kemasan teh cap Nyapu.

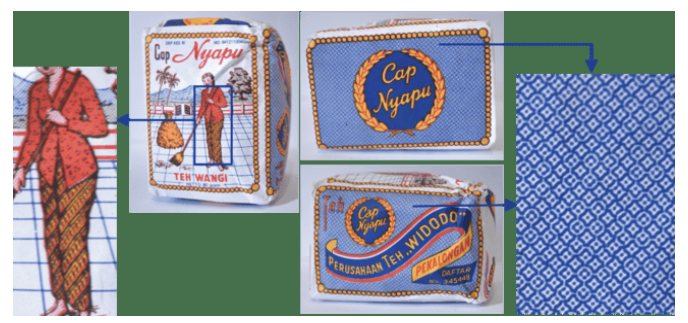

Gambar 10. Penggunaan motif dalam kebaya merah, jarik batik dan pada background dalam visual kemasan teh Cap Nyapu.

(Sumber: Dokumentasi Ayu Latifah)

Pada kebaya merah, motif tiga titik ini menyerupai motif bunga yang jika dilihat dari jarak yang jauh akan tampak seperti titik saja. Motif tiga titik ini merepresentasikan kelopak bunga. Sementara itu, terlihat motif batik pada jarik yang dikenakan oleh perempuan yang sedang menyapu. Motif batik ini merupakan motif batik parang, sebagaimana memiliki ciri sebagai berikut (1) memiliki motif garis diagonal yang sejajar dengan sudut kemiringan 45\%, dengan (2) motif seperti huruf $S$ dan seperti senjata parang yang tajam. Efek visual yang dihasilkan dari kedua motif tersebut mengesankan akan detailnya suatu gambar dan mengidentifikasikan suatu budaya tertentu yang akan dipaparkan lebih lanjut pada sub-bab makna visual.

Motif yang ketiga tampak pada sisi kanan dan kiri dalam kemasan teh Cap Nyapu. Motif ini tampak menyerupai motif batik kawung. Jika diamati dari jauh, motif biru tua tersebut akan tampak seperti warna biru muda yang mempunyai titik putih tengah saja. Penggunaan motif tersebut sebagai background memberikan efek visual yang harmonis dan tidak membosankan.

\section{c. Hiasan tepi (border)}

Dalam visual kemasan teh Cap Nyapu terdapat ilustrasi sebuah border atau hiasan tepigambar yang menjadi tepi batas yang mengelilingi keseluruhan ilustrasi dalam visual kemasan teh Cap Nyapu. Border yang terdapat dalam ilustrasi teh Cap Nyapu digambarkan sebagai lingkaran berwarna kuning yang berjajar dan membentuk garis luar sebagai batas ilustrasi dalam kemasan teh Cap Nyapu. Penggunaan border tersebut memberikan kesan ilustrasi yang penuh dan harmonis dikarenakan menggunakan warna yang memiliki dominasi yang digunakan dalam visual kemasan teh Cap Nyapu, yaitu warna kuning. Penggunaan border juga merujuk pada gaya Victorian, dimana salah satu cirinya adalah adanya penggunaan framing pada gambar dan biasanya berupa ornamen. 


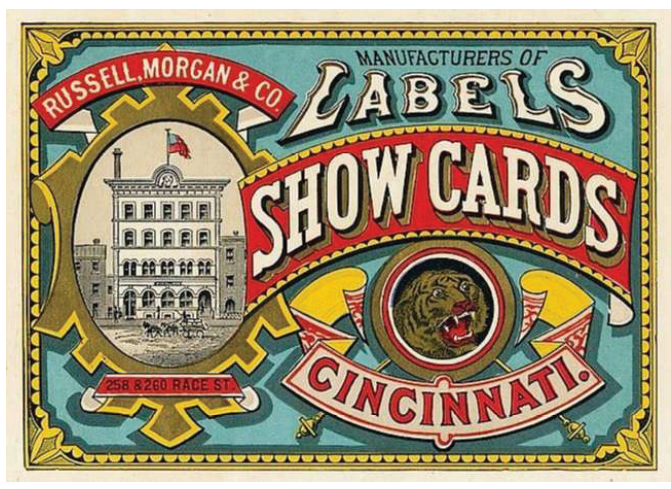

Gambar 11. Penggunaan border dalam poster dalam gaya Victorian

(Sumber: http://poulwebb.blogspot. com/2015/10/trade-cards-part-5.html)

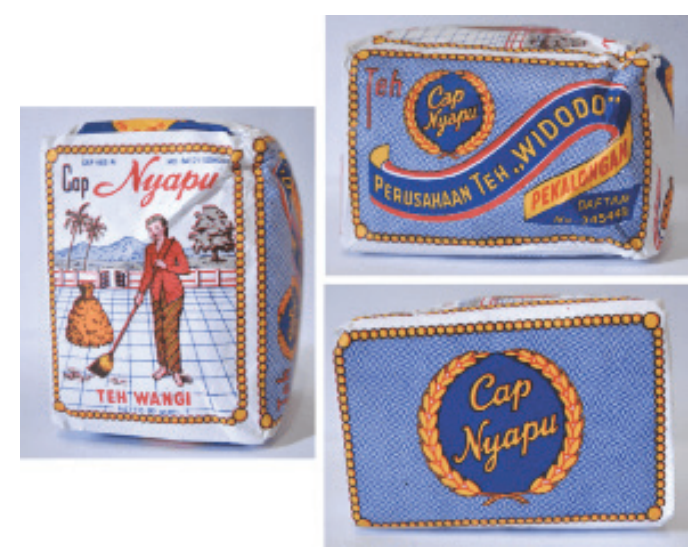

Gambar 12. Penggunaan border dalam visual kemasan teh Cap Nyapu.

(Sumber: Dokumentasi Ayu Latifah)

\section{Komposisi}

Komposisi dalam visual kemasan teh Cap Nyapu terdiri dari komponen-komponen sebagai berikut yaitu

a. Warna

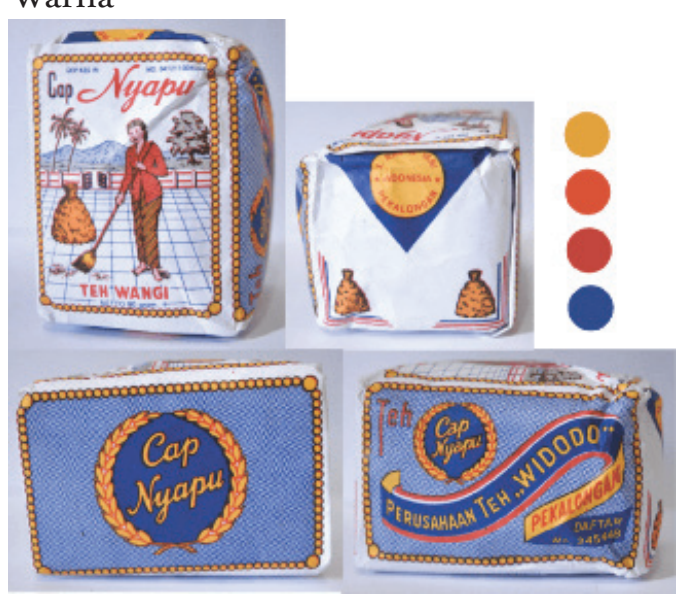

Gambar 13. Dominasi warna merah, orange, kuning dan biru, serta dua objek berwarna hijau pada visual kemasan teh Cap Nyapu. (Sumber: Dokumentasi Ayu Latifah)
Warna yang digunakan dalam visual kemasan teh Cap Nyapu didominasi oleh perpaduan warna merah, orange, kuning dan biru. Selain itu, terdapat dua objek yang menggunakan warna hijau dan satu objek berwarna coklat. Warna merah mempunyai karakter cepat, kuat, berani, positif, agresif. Warna merah terdapat pada kebaya yang digunakan oleh perempuan dalam kemasan teh cap Nyapu. Warna orange memiliki karakter semangat, yang terdapat pada yang dikenakan prempuan. Warna kuning berkarakter ramah, gembira, riang, cerah, hangat. Warna biru memiliki karakter melankolis, mendalam, sedih, sendu, terdapat pada font dalam visual kemasan teh cap Nyapu.

Warna merah, orange dan kuning masuk dalam kategori warna panas. Disebut warna panas karena merupakan simbol dari api dan musim kemarau. Warna panas memberikan citra visual yang hangat. Warna biru merupakan kategori warna dingin. Disebut warna dingin karena warna-warna dalam kelompok ini merupakan simbol dari hijau dedaunan dan birunya langit dan laut. Warna dingin mempunyai kesan sejuk, damai, alami dan bersahaja.

Warna merah, orange dan kuning terdapat pada tipografi, frame, kebaya, pagar, gabah, pita dan sapu. Sementara warna biru terdapat pada pegunungan, background bermotif, pita, garis lantai dan segitiga pada sisi atas dan bawah desain kemasain teh Cap Nyapu. Warna hijau terdapat pada sawah dan pohon yang berada pada sisi kiri bagian depan visual kemasan teh Cap Nyapu. Warna coklat terdapat pada jarik batik yang dikenakan oleh perempuan yang sedang menyapu.

Perpaduan antara warna panas dan dingin ini, dengan dominasi warna panas memberikan kesan santai dan 'hangat' dalam visual kemasan teh cap Nyapu.

\section{Tipografi}

Dalam sebuah karya desain, tipografi merupakan komponen yang tidak kalah 
pentingnya dengan komponen visual lainnya. Tipografi dalam desain berfungsi untuk menyampaikan pesan atau informasi. Dalam mengaplikasikan tipografi perlu diperhatikan beberapa hal diantaranya ukuran huruf, penggunaan huruf kapital, penggunaan huruf dekoratif, spasi, tanda baca dan sebagainya untuk disesuaikan dengan konteks pesan atau informasi yang akan disampaikan. Beberapa tipografi yang terdapat dalam visual kemasan teh Cap Nyapu adalah sebagai berikut:

a. Cap Nyapu

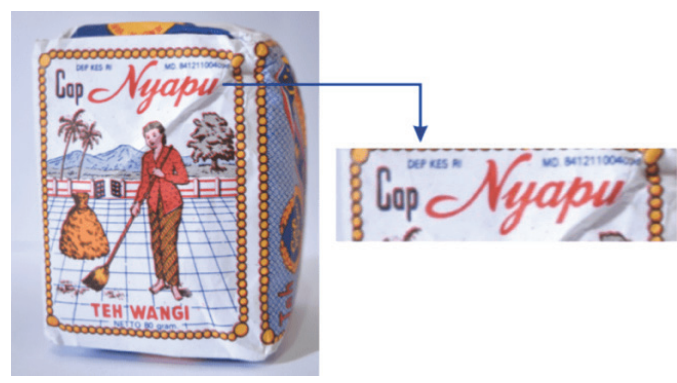

Gambar 14. Tipografi "Cap Nyapu" dalam visual kemasan teh Cap Nyapu

(Sumber: Dokumentasi Ayu Latifah)

Pada kalimat "Cap Nyapu" terdapat dua karakter dan jenis huruf yang berbeda. Pada kata "Cap" merupakan kategori huruf sans serif atau tanpa kaki. Sebagaimana huruf sans serif mempunyai ciri sebagai berikut (1) garis melengkung berbentuk square/persegi, (2) terdapat perbedaan kontras yang halus, dan (3) bentuk mendekati penekanan ke arah garis vertikal. Kata "Cap" menggunakan warna hitam dengan rangkap warna merah dibelakangnya jika dilihat secara detail.

Sementara itu, pada kata "Nyapu" merupakan kategori huruf script dengan ciri sebagai berikut (1) menyerupai tulisan tangan (handwriting) dan umumnya terkesan anggun, (2) biasanya huruf script ditulis miring ke kanan, (3) scipt selalu memiliki tebal tipis tulisan yang bervariasi dalam setiap hurufnya. Kata "Nyapu" menggunakan warna merah dan memiliki karakter huruf handwritten. Font ini sangat identik dengan model tulisan tangan latin bergaya klasik. Script digunakan untuk memberikan kesan santai pada desain. b. Teh Wangi

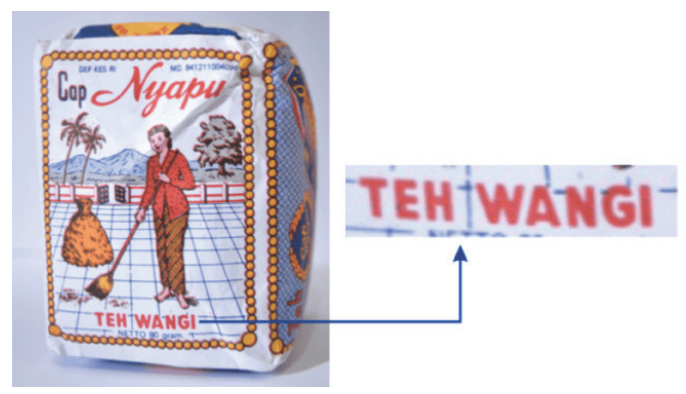

Gambar 15. Tipografi "TEH WANGI" dalam visual kemasan teh Cap Nyapu (Sumber: Dokumentasi Ayu Latifah)

Penulisan "TEH WANGI" terletak pada sisi bawah bagian depan visual kemasan teh Cap Nyapu dengan menggunakan huruf kapital dan berwarna merah. Merupakan tipe huruf sans serif. Penggunaan huruf sans serif memberikan kesan santai dan dinamis, namun dengan perpaduan warna merah dan penggunaan huruf kapital memberikan kesan berani dan tegas.

c. Cap Nyapu

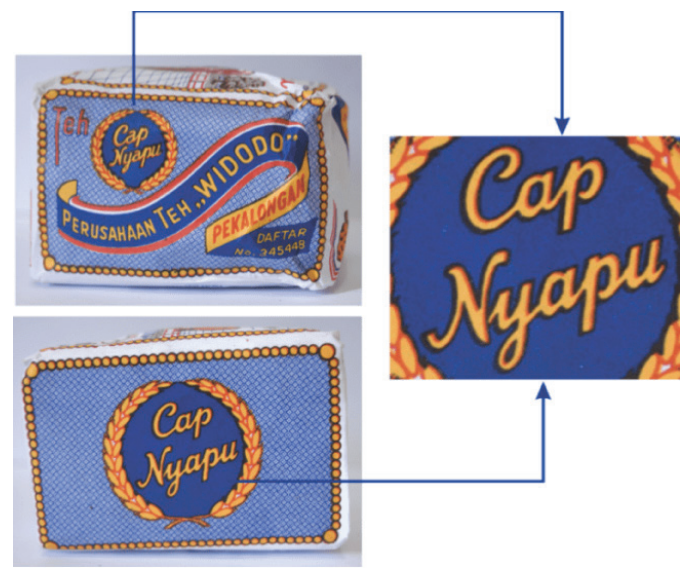

Gambar 16. Tipografi "Cap Nyapu" dalam visual kemasan teh Cap Nyapu (Sumber: Dokumentasi Ayu Latifah)

Penulisan "Cap Nyapu” ini berwarna kuning dan terletak didalam lingkaran biru. Memiliki ciri huruf script yaitu sebagai berikut (1) menyerupai tulisan tangan (handwriting) dan umumnya terkesan anggun, (2) biasanya huruf script ditulis miring ke kanan, (3) scipt selalu memiliki tebal tipis tulisan yang bervariasi dalam setiap hurufnya 
d. Alamat produksi dan berat bersih

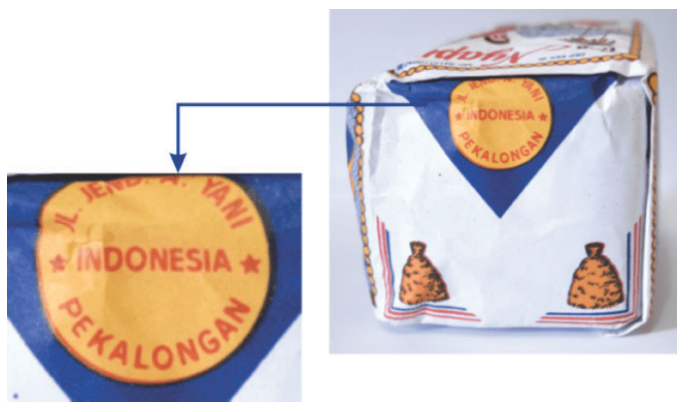

Gambar 17. Tipografi alamat produksi dalam visual kemasan teh Cap Nyapu

(Sumber: Dokumentasi Ayu Latifah)

Terdapat alamat produksi yang tertera pada sisi atas dan bawah desain kemasan teh Cap Nyapu. Kedua keterangan tersebut menggunakan jenis huruf sans serif berwarna merah dan terletak didalam dan mengikuti garis lingkaran berwarna kuning. Dilihat dari segi warna, informasi mengenai alamat produksi dan berat bersih memiliki tingkat keterbacaan yang baik. Namun jika dilihat dari style-nya mengikuti garis dalam lingkaran mempunyai kesan estetik namun tidak ringkas untuk dibaca.

e. Teh

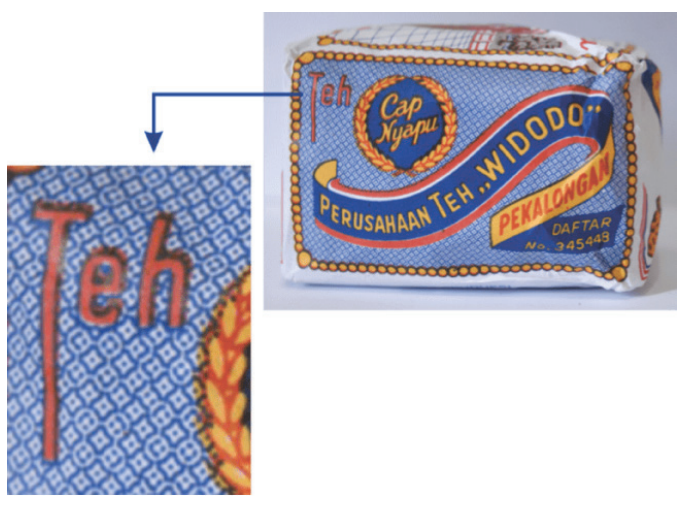

Gambar 18. Tipografi "Teh" dalam visual kemasan teh Cap Nyapu

(Sumber: Dokumentasi Ayu Latifah)

Penulisan teh menggunakan huruf serif berwarna merah dengan outline hitam. Huruf "T" memiliki garis yang panjang, memiliki kesan mencolok dan unik. f. Perusahaan Teh Widodo

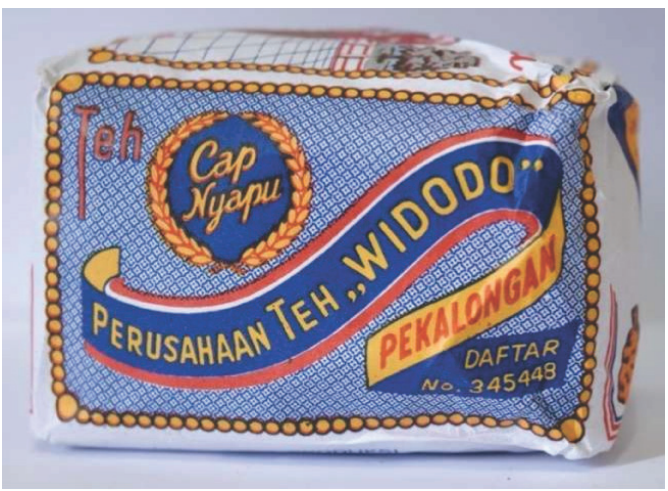

Gambar 19. Tipografi "Perusahaan Teh Widodo" dalam visual kemasan teh Cap Nyapu (Sumber: Dokumentasi Ayu Latifah)

Penulisan "Perusahaan Teh Widodo" memiliki bentuk huruf sans serif dengan penggunaan huruf kapital berwarna kuning. Huruf kapital yang digunakan tampak memiliki perbedaan ukuran dan spasi. Pada kata "perusahaan" ditulis dengan huruf kapital yang saling berhimpitan, kemudian pada kata "teh" memiliki huruf $\mathrm{T}$ dengan tiang atau garis lurus yang lebih tinggi dengan spasi yang sedikit renggang. Sementara pada kata "Widodo" berhuruf kapital yang memiliki ukuran huruf paling besar diantara ketiga kata tersebut dan memiliki jarak yang paling renggang. Hal tersebut bisa saja dimaksudkan sebagai perspektif dari visual itu sendiri dimana pada kalimat "perusahaan teh Widodo" ditulis diatas ribbon/pita. Pita merupakan benda yang lentur dan biasanya terbuat dari material kain sehingga dalam realita pun, besar kecilnya bentuk huruf yang dicetak diatas pita tergantung pada dekat atau jauhnya pita yang cekung atau cembung terkena terhadap pengamat visual tersebut.

\section{Ilustrasi}

Ilustrasi merupakan visualisasi dari suatu tulisan yang menggunakan teknik skesa, lukisan, fotografi atau teknik seni rupa lainnya yang lebih menekankan hubungan subjek dengan tulisan yang dimaksud. Ilustrasi 
dapat menjadi media yang tepat dalam menyampaikan isi pesan atau informasi yang ingin disampaikan. Ilustrasi dalam visual kemasan teh Cap Nyapu menggambarkan suasana desa yang asri, terlihat dari pegunungan, sawah dan pepohonan yang rindang. Seorang perempuan mengenakan kebaya merah dengan jarik bermotif batik tengah menyapu remahan gabah disebuah teras yang luas.

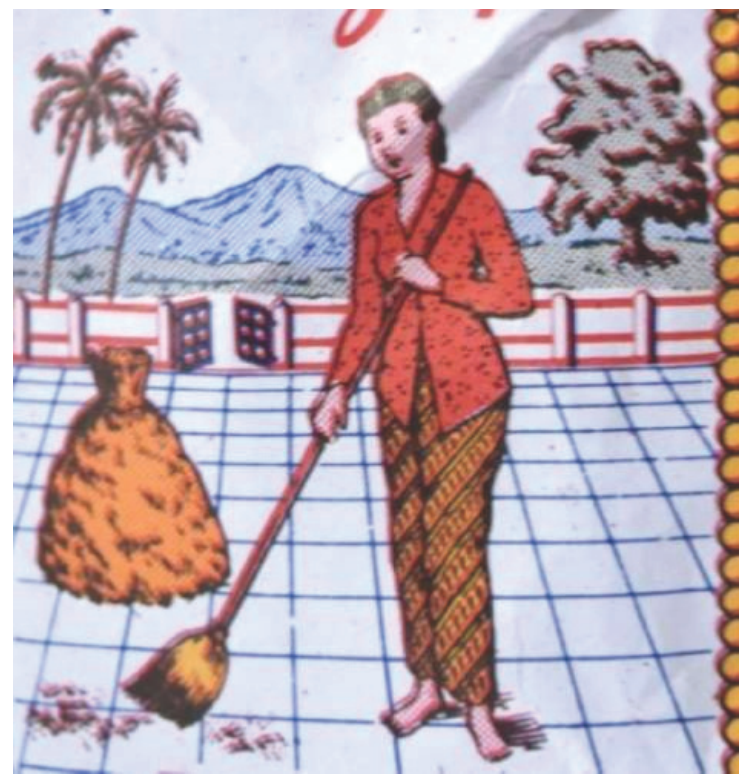

Gambar 20. Ilustrasi dalam visual kemasan teh Cap Nyapu

(Sumber: Dokumentasi Ayu Latifah)

\section{Makna Visual}

Setelah memahami visual kemasan teh Cap Nyapu melalui efek visual serta teknikteknik yang digunakan, kemudian masuk dalam tahap memaknai visual dari gambar yang ditampilkan dalam visual kemasan teh Cap Nyapu, sebagai berikut: Penggunaan kata "Nyapu" dalam merk teh Cap Nyapu mencerminkan nilai budaya dari istilah nyapu itu sendiri. Nyapu berasal dari bahasa Jawa dari asal kata sapu, dengan kata kerja menyapu yang kurang lebih artinya adalah membersihkan debu atau kotoran yang berada dilantai atau alas tertentu menggunakan alat yang disebut sapu. Istilah nyapu (atau menyapu dalam bahasa Indonesia) khas dengan bahasa Jawa yang kerap kali menghilangkan kata depan me- atau penambahan ny- pada kata kerja atau kata benda tertentu, seperti misalnya nyapu (sapu, menyapu), nyambut (sambut, menyambut), nyekseni (menyaksikan), nyeritani (menceritakan), dan sebagainya.

Kegiatan menyapu pada umumnya dilakukan pada pagi saat masyarakat memulai aktivitasnya ataupun sore hari setelah melaksanakan kegiatannya masingmasing. Lantaran adanya mitos atau disebut pamali dalam masyarakat Jawa apabila menyapu dilakukan pada malam hari, karena jika melakukannya dipercaya akan dapat membuang rezeki yang sudah dikumpulkan dalam satu hari tersebut. Sementara itu, kegiatan menyapu pada zaman dahulu umumnya tidak dilakukan oleh semua golongan stratifikasi sosial dalam budaya masyarakat Jawa. Adapun stratifikasi sosial dalam masyarakat Jawa menurut Koentjananingrat dipaparkan sebagai berikut:

Didalam kenyataan hidup masyarakat orang Jawa, orang masih membedabedakan antara orang priyayi dan yang terdiri dari pegawai negeri dan kaum terpelajar dengan orang kebanyakan yang disebut wong cilik, seperti petanipetani, tukang-tukang dan pekerja kasar lainnya. Dalam kerangka susunan masyarakat ini, secara bertingkat yang berdasarkan atas gengsi-gengsi itu, kaum priyayi merupakan lapisan teratas, sedangkan wong cilik menjadi lapisan masyarakat bawah. (Koentjananingrat, 2010: 344)

Wong cilik diartikan dengan kaum pekerja/proletar yang biasanya menjadi buruh pekerjaan kasar yang berpengaruh pada perbedaan aktivitas sehari-harinya dengan kaum priyayi. Golongan priyayi tidak selayaknya membersihkan rumahnya sendiri pada masa itu. Dari aktivitas menyapu yang menjadi ilustrasi dalam visual kemasan teh Cap Nyapu ini, dapat disimpulkan bahwa perempuan tersebut bukan berasal dari golongan priyayi melainkan menjadi gambaran dari wong cilik. Berikut ini adalah beberapa dokumentasi perempuan yang mengenakan kebaya dengan jarik bermotif parang. 


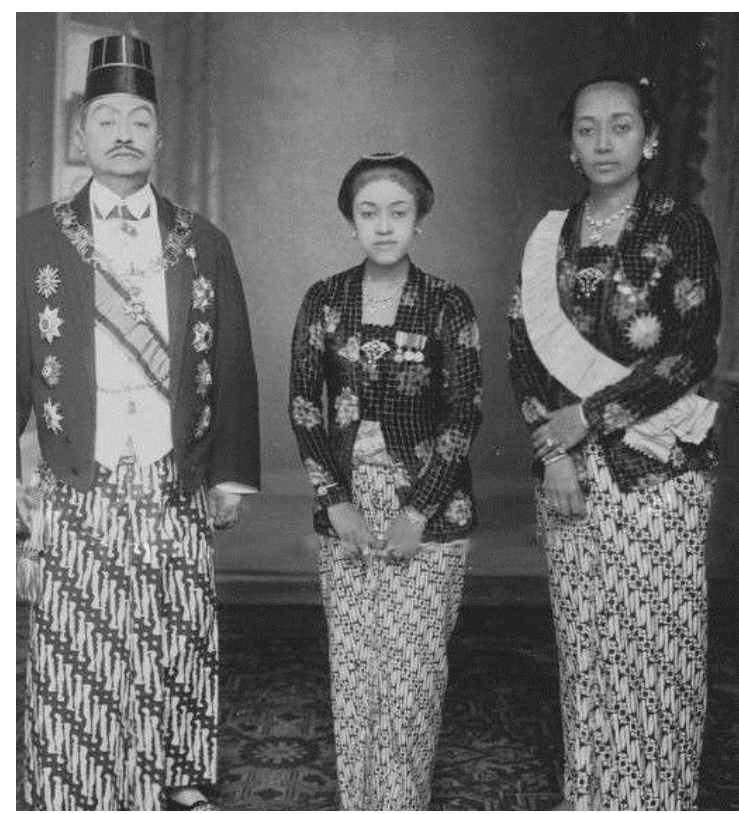

Gambar 21. Sunan Pakubuwono X dan keluarganya. (Sumber: superbridezilla.blogspot.com)

Terdapat beberapa perbedaan yang cukup kentara antara golongan priyai dengan wong cilik atau kaum menengah kebawah saat mengenakan jarik batik bermotif parang. Golongan priyai menggunakan aksesoris maupun perhiasan seperti kalung, anting maupun hiasan di rambut yang digelung/konde. Golongan priyai juga menggunakan atasan yang lebih tebal dan terlihat seperti kain dengan kualias yang lebih baik daripada kebaya yang dikenakan oleh orang biasa. Berdasarkan hasil pengamatan diatas, dapat disimpulkan perempuan dalam visual kemasan teh Cap Nyapu merupakan golongan wong cilik, dikarenakan perempuan pada visual kemasan teh Cap Nyapu tidak mengenakan aksesoris atau perhiasan satupun, berbeda dengan golongan priyai/ningrat saat itu yang mengenakan kebaya dengan kain yang lebih tebal dan mengenakan perhiasan dan aksesoris yang merepresentasikan kelas sosialnya.

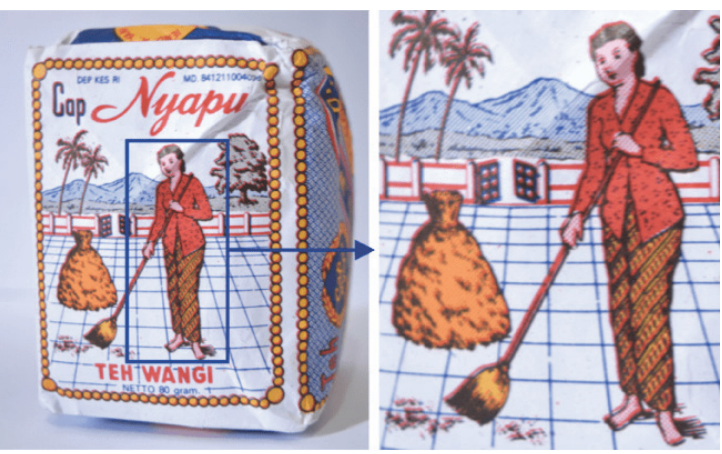

Gambar 22. Sosok perempuan yang tengah menyapu dalam ilustrasi visual kemasan teh Cap Nyapu. (Sumber: Dokumentasi Ayu Latifah)
Gaya desain yang digunakan dalam visual kemasan teh Cap Nyapu, adalah gaya Victorian dengan ciri-ciri yang telah disebutkan pada bab 2 yaitu (1) Penuturan visual yang 'didaktik' dan 'naratif', yaitu berusaha menjelaskan dengan selengkap-lengkapnya. (2) Visualiasasi dan pemakaian tipografi serta border atau hiasan pinggir secara penuh, tanpa meninggalkan bidang kosong. (3) Ada anggapan bahwa setiap bidang harus dikuasai dengan cara diisi berbagai unsur grafis. Ketiga ciri tersebut terlihat dalam visual kemasan teh Cap Nyapu yang mendeskripsikan secara visual kegiatan menyapu tersebut dengan latar belakang dan latar tempat yang detail dan naratif. Selain itu, penggunaan border pada tipografi mencerminkan gaya ilustrasi Victorian pada masa tersebut. Berlandaskan ilustrasi dalam visual kemasan teh Cap Nyapu, analisis yang dijabarkan adalah sebagai berikut.

a. Figur perempuan yang tengah menyapu menjadi point of interest pada ilustrasi dalam visual kemasan teh Cap Nyapu. Perempuan tersebut tampak mengenakan kebaya berwarna merah yang dipadukan dengan kain jarik. Jarik merupakan kain khas Nusantara yang sangat melekat dalam kehidupan masyarakat Jawa, terutama Jawa Tengah dan Jawa Timur. Jarik adalah sebuah sebutan untuk kain khas Jawa yang mempunyai motif batik dengan berbagai corak.

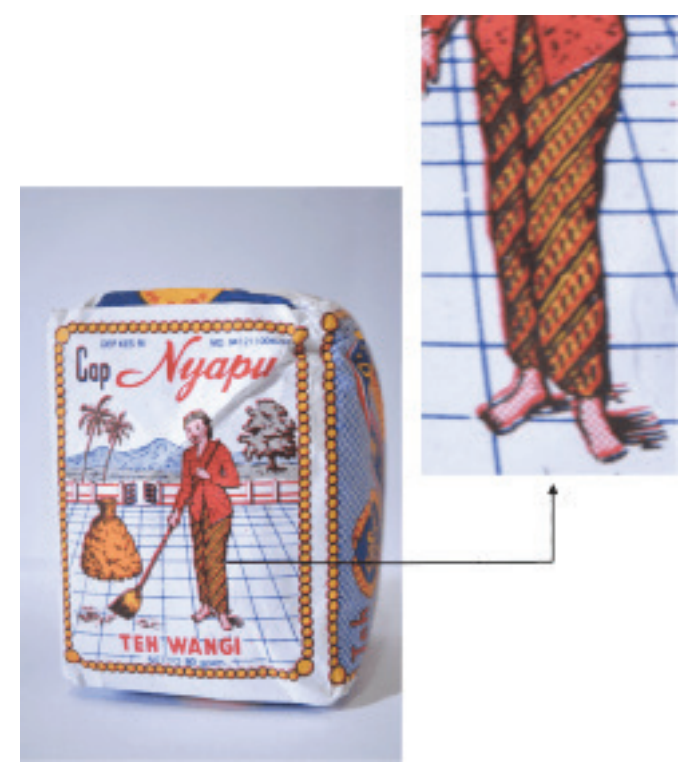

Gambar 23. Jarik bercorak batik parang yang dikenakan oleh perempuan dalam ilustrasi visual kemasan teh Cap Nyapu. (Sumber: Dokumentasi Ayu Latifah) 


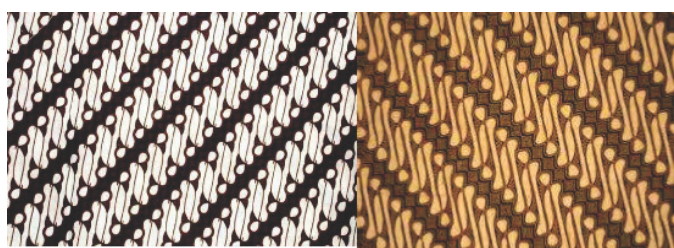

Gambar 24 . Motif batik Parang.

(Sumber: infobatik.id, indonesianbatik.com)

Dilansir oleh Kumparan..com, jarik dalam bahasa Jawa memiliki makna 'Aja gampang sirik', atau dalam Bahasa Indonesia berarti jangan mudah iri hati. Ketika memakai jarik, seseorang akan berjalan dengan hati-hati. Perempuan akan terkesan lemah lembut dan berjalan lebih anggun ketika memakai jarik. Namun saat ini, jarik hanya digunakan pada saat hari pernikahan dan acaraacara sakral lainnya. Pada jaman dahulu, masyarakat Jawa biasa menggunakan kain jarik dalam kehidupan sehari-hari, mulai dari dipakai sebagai bawahan, alas tidur bayi, kain untuk menggendong bayi, hingga alas dan kain penutup untuk orang meninggal. Tak hanya itu, perempuan yang baru selesai melahirkan juga dianjurkan untuk memakai jarik agar sikap tubuhnya terjaga dan untuk mempercepat proses pemulihan.

Dulu dan bahkan hingga saat ini, di desa-desa jarik digunakan untuk menutup tubuh dari dada hingga lutut atau betis ketika mereka mandi di sungai. Biasanya jarik itu dalam Bahasa Jawa disebut telesan atau berarti basahan dalam Bahasa Indonesia. Namun di era modern saat ini, fungsi jarik telah banyak mengalami perubahan. Mayoritas penggunaan kain jarik saat ini hanya digunakan sebagai padu padan kebaya saat menghadiri acara pernikahan atau wisuda, yang digunakan sebagai selendang, atau bahkan dijahit ulang untuk dijadikan baju atau rok.

Jarik yang dikenakan oleh perempuan dalam visual kemasan teh Cap Nyapu menggunakan motif batik pada umumnya. Berdasarkan pengamatan visual motif batik pada kain jarik tersebut, tampak sesuai dengan ciri motif batik Parang, yaitu memiliki motif garis diagonal yang sejajar dengan sudut kemiringan $45 \%$, dengan motif seperti huruf $S$ dan seperti ombak laut.

Mengutip sumber dari Informasi Batik Indonesia, motif batik parang merupakan salah satu motif batik tertua di Indonesia. Kata parang beerasal dari Pereng atau lereng atau tebing yang memiliki bentuk garis diagonal. Dalam setiap motif batik biasanya akan terdapat susunan motif yang membentuk seperti huruf $S$, saling terkait satu dengan lainnya, saling menjalin dan melambangkan sbeuah kesinambungan. Bentuk huruf $S$ tersebut diadaptasi dari bentuk ombak lautan, menggambarrkan semangat yang tidak pernah padam.

Motif batik parang merupakan batik asli Indonesia yang sudah ada sejak zaman Keraton Maratam Kartasura (Solo). Diciptakan oleh pendiri keratin Mataram, sehingga motif ini menjadi pedoman utama dalam menentukan derajat kebangsaawanan seseorang. Bahkan pada jaman dulu motif parang hanya boleh dikenakan raja dan keturunannya.

Secara filosofis, motif batik Parang memang memiliki kandungan makna yang tinggi. Bahasa simbol yang terkandung didalamnya adalah sebuah pesan bahwa sebagai manusia hendaknya tidak menyerah dalam mengarungi kehidupan, sebagaimana ombak di samudera yang tak pernah lelah untuk bergerak. Bentuk motif parang yang saling berkesinambungan, menggambarkan jalinan hidup yang tidak pernah putus, selalu konsisten dalam upaya untuk memperbaiki diri, memperjuangkan kesejahteraan maupun hubungan antara alam, manusia dengan manusia dan manusia dengan Tuhannya.

b. Pegunungan dan pepohonan dan langit biru yang menjadi latar belakang dari ilustrasi perempuan yang tengah menyapu tersebut merepresentasikan suasana siang hari yang asri dan jauh dari hiruk 
pikuk kota, yang berarti latar tempat dari ilustrasi tersebut adalah disebuah desa yang asri, sejuk dan tentram.

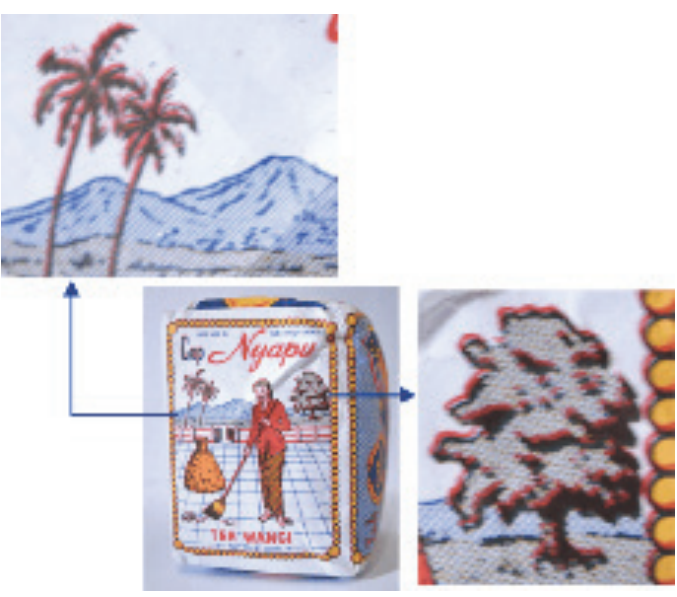

Gambar 25. Ilustrasi pemandangan alam; pegunungan, sawah, dua pohon kelapa sawit dan pohon yang rimbun.

(Sumber: Dokumentasi Ayu Latifah)

Desa sebagai tempat kediaman yang tetap pada masyarakat orang Jawa, didaerah pedalaman, adalah suatu wilayah hukum yang sekaligus menjadi pusat pemerintahan tingkat daerah paling rendah. Secara administratif desa langsung berada dibawah kekuasaan pemerintah Kecamatan dan terdiri dari dukuh-dukuh. Tiap-tiap wilayah bagian desa diketuai oleh kepala dukuh. Disini dijumpai sejumlah perumahan penduduk beserta tanah-tanah pekarangannya yang satu sama lain dipisah-pisahkan dengan pagar-pagar bambu atau tumbuh-tumbuhan. (Koentjaraningrat, 2010:331).

c. Remahan gabah sebagai subjek yang disapu, terlihat dari adanya buntalan gabah yang masih terikat.

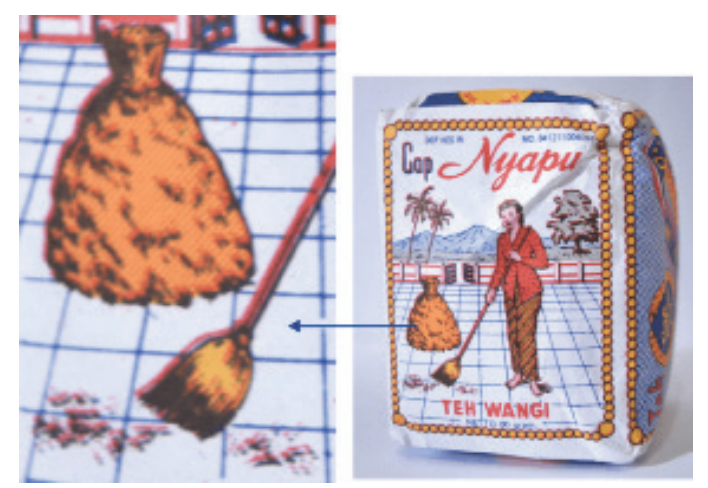

Gambar 26. Ilustrasi gabah yang disapu oleh perempuan berkebaya merah dan bermotif jarik batikpada visual kemasan teh Cap Nyapu. (Sumber: Dokumentasi Ayu Latifah)
Pada masa lalu padi yang telah dipotong dari tangkainya umumnya lalu diikat menjadi satu. Besarnya diameter ikatan umumnya segenggaman tangan orang dewasa. Ikatan-ikatan padi ini kemudian diusung dan dijemur di atas kepang atau tikar. Jika sudah kering lantas disusun bertumpuk sehingga membentuk gundukan-gundukan seperti gunung kecil. Tumpukan padi demikian ini umumnya disimpan di dalam tempat yang dinamakan lumbung. Ada pula yang disimpan dalam ruang-ruang terbuka namun beratap rapat. Jika akan dijadikan padi orang tinggal mengambil ikatan-ikatan itu, mengilesnya (merontokkan dengan diinjak-injak dengan gerakan setengah memutar).

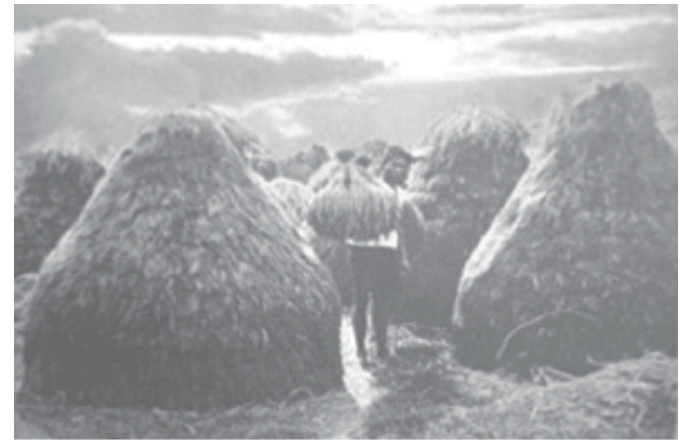

Gambar 27. Menyimpan padi tempo dulu. (Sumber: https:wordpress.com/2012/10/02/ menyimpan-padi-tempo-dulu)

Gambar di atas menuggambarkan wujud tumpukan padi di masa lalu yang di zaman sekarang sudah sangat sulit ditemukan lagi. Penyimpanan padi yang dilakukan di zaman sekarang hampir selalu dalam bentuk gabah kering yang telah dirontokkan dari tangkainya. Lebih praktis, efisien, tidak menyita ruang dan lebih mudah dalam pemrosesan menjadi beras.

d. Teras yang luas dengan pagar yang terbuka sebagai latar tempat pada ilustrasi teh cap Nyapu.

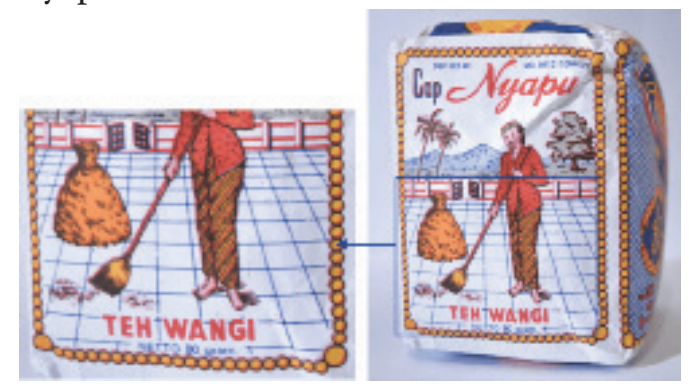

Gambar 28. Ilustrasi teras yang luas dalam visual kemasan teh Cap Nyapu. (Sumber: Dokumentasi Ayu Latifah) 
Teras tersebut menunjukkan sebuah rumah yang cukup besar karena mempunyai teras yang luas. Rumah dapat menunjukkan kelas sosial tertentu. Seperti yang dipaparkan oleh Kartodirdjo, rumah-rumah prriyayi tinggi berukuran besar, dibuat dari batu, seperti halnya rumah-rumah pegawai menengah dan pegawai tinggi, sedang pegawai-pegawai rendahan bertempat tinggal dirumahrumah kayu, dan penduduk desa di rumah-rumah bambu. (Kartodirdjo, 1999:215). Ilustrasi teras dalam visual kemasan teh Cap Nyapu digambarkan tidak berwarna dan hanya menggunakan warna biru pada outline/garis-luarnya.

\section{Analisis Teh Cap Soklat}

Teh Cap Soklat merupakan teh yang diproduksi sejak tahun 1957 oleh PT. Teh Kartini Nasional yang terletak di Batang, Jawa Tengah. PT. Teh Kartini Nasional memproduksi dua merk teh yaitu teh Cap Soklat dan teh Dandang, yang lebih familiar dipasaran saat ini. Visual kemasan dalam teh Cap Soklat menampilkan ilustrasi tanaman coklat yang menjadi representasi visual dari merk teh itu sendiri, yaitu Cap Soklat. Adapun penggunaan kata soklat diketahui berasal dari kata tjoklat dalam bahasa Melayu, coklat dulunya ditulis" tjoklat" dalam ejaan lama.

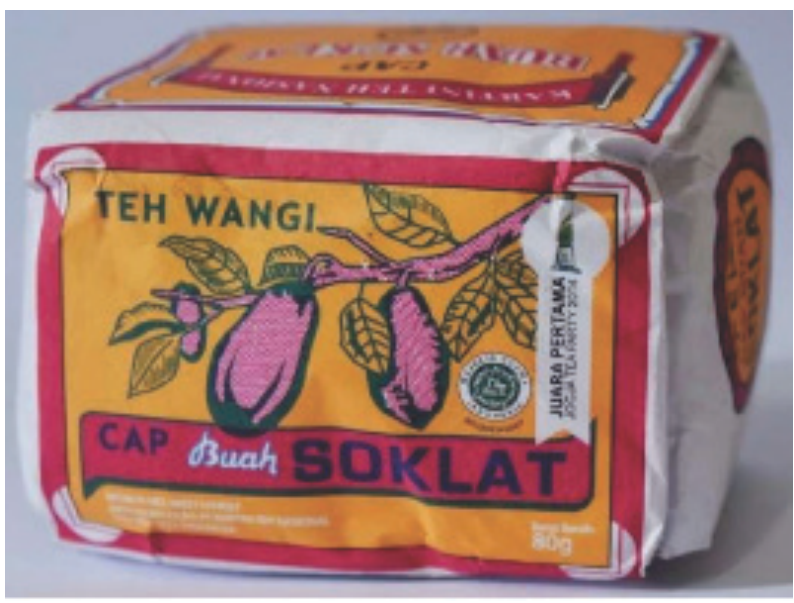

Gambar 29. ilustrasi tanaman coklat yang terdapat pada sisi depan visual kemasan teh Cap Soklat. (Sumber: Dokumentasi Ayu Latifah)

Dalam visual kemasan teh Cap Soklat terdapat ilustrasi tanaman kakao dengan dua buah kakao, yang juga dilengkapi dengan tipografi sebagai fungsi informasi produk. Visual kemasan teh Cap Soklat didominasi warna kuning dan merah dilengkapi dengan warna lainnya yaitu; hijau, merah muda, dan biru. Adapun penjabaran dalam analisis visual kemasan teh Cap Soklat adalah sebagai berikut

\section{Teknologi Visual}

Teh Cap Soklat menggunakan ilustrasi dan komponen-komponen visual tanpa terlihat mengikuti tren desain masa kini. Terlepas dari hal tersebut, teknologi visual memiliki kaitannya dengan bentuk, makna, dan efek visualnya. Visual kemasan teh cap Soklat menggunakan teknik ilustrasi manual yang kemudian dicetak menggunakan teknik offset. Terdapat beberapa efek visual dalam visual kemasannya yaitu:

a. Half-tone

Half-tone diterapkan untuk menghasilkan gambar agar terlihat realis.

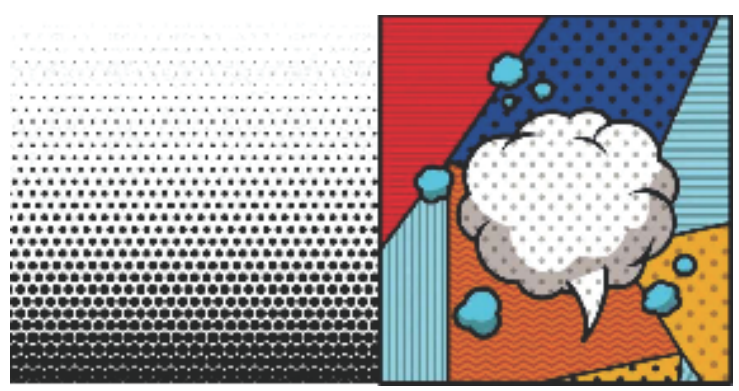

Gambar 30. Halftone

(Sumber: https://www.freepik.com/)

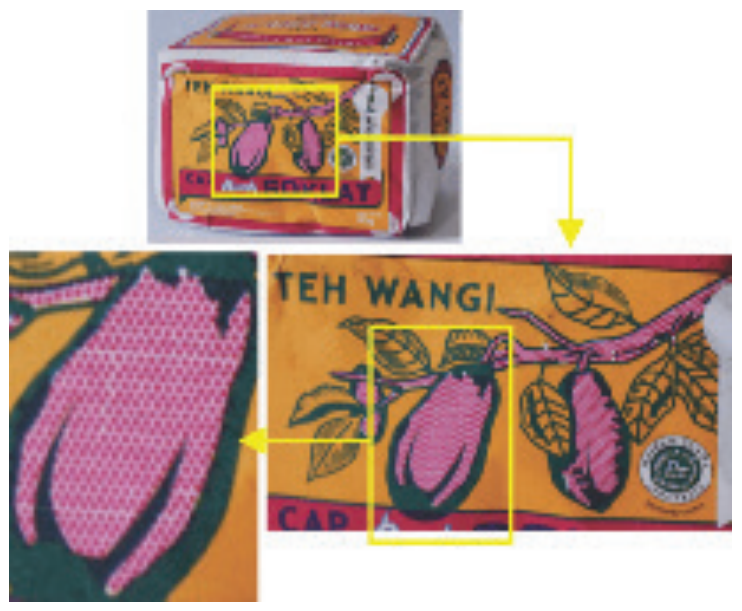

Gambar 31. Half-tone dalam visual kemasan teh Cap Soklat yang terdapat pada ilustrasi tanaman kakao. (Sumber: Dokumentasi Ayu latifah)

Half-tone yang terlihat pada ilustrasi buah kakao yang dipenuhi dnegan titik-titik (dot) berwarna merah yang mempunyai jarak 
yang sama secara konsisten. Hal yang sama juga didapati pada ranting dari tanaman kakao.

\section{Komposisi}

a. Warna

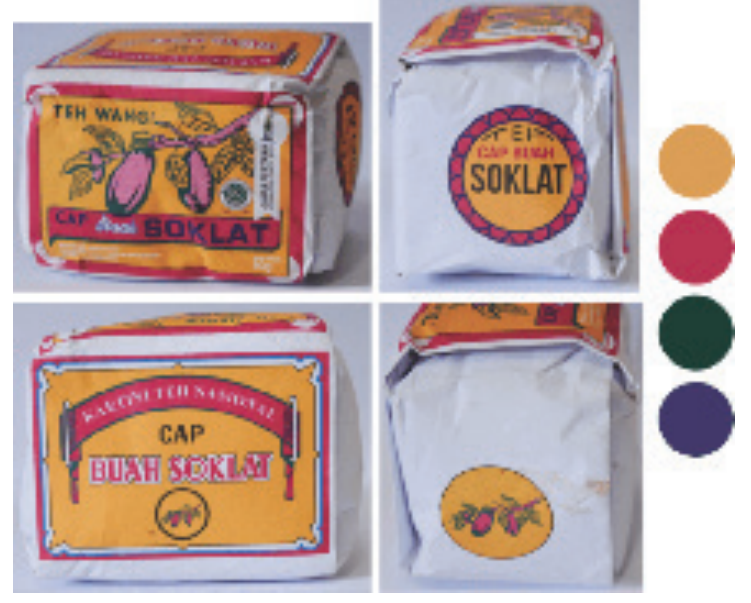

Gambar 32. Dominasi warna merah dan jingga (orange) dan penggunaan waran hijau dan biru yang terdapat dalam visual kemasan the Cap Soklat. (Sumber: Dokumentasi Ayu latifah)

Warna merupakan salah satu elemen visual yang berperan sangat penting, karena warna pada sebuah objek visual mempunyai sifat yang langsung tertangkap oleh mata terlebih dahulu dibandingkan dengan unsurunsur lainnya dalam desain. Warna biasanya digunakan sebagai simbol pembeda terhadap konten seperti produk, label, kategori, karakteristik tertentu atau juga hanya sebagai representatif dari emosi manusia. Dalam visual kemasan teh Cap Soklat menggunakan warna orange, merah, hijau, merah muda dan biru. Warna merah mempunyai karakter cepat, kuat, berani, positif, agresif. Warna orange memiliki karakter semangat, anugrah. Warna kuning berkarakter terang, ramah, gembira, riang, cerah, hangat. Warna biru memiliki karakter melankolis, mendalam, sedih, sendu. Sementara warna hijau memiliki karakter segar, tumbuh, muda dan hidup. Warna merah, orange dan kuning masuk dalam kategori warna panas. Warna panas melambangkan api dan musim kemarau sehingga memberikan citra visual yang hangat. Sementara warna biru merupakan kategori warna dingin. Disebut warna dingin karena warna-warna dalam kelompok ini merupakan simbol dari hijau dedaunan dan birunya langit dan laut. Warna dingin mempunyai kesan sejuk, damai, alami dan bersahaja. b. Tipografi

Beberapa tipografi yang terdapat dalam visual kemasan teh Cap Soklat adalah sebagai berikut:

1. "Teh Wangi”

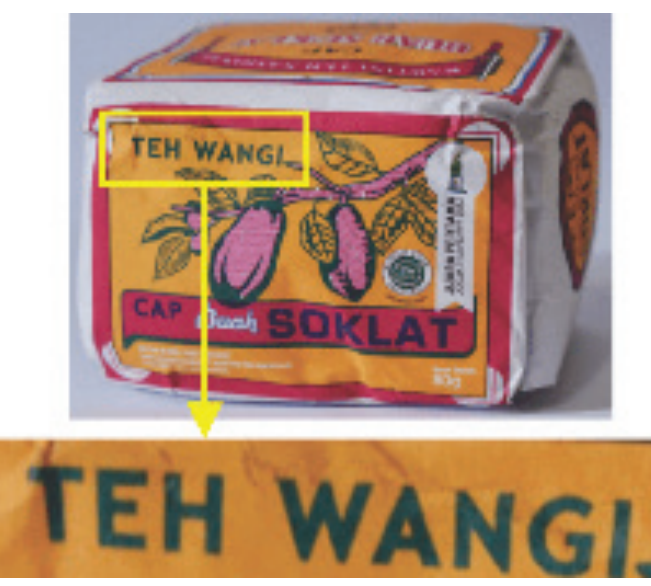

Gambar 33. Tipografi "teh wangi” dalam visual kemasan teh Cap Soklat.

(Sumber: Dokumentasi Ayu Latifah)

Sama halnya dengan teh Cap Nyapu, teh Cap Soklat juga memiliki keterangan "teh wangi" dalam visual kemasannya. Yang membedakan adalah tata letak dan pemilihan warna yang digunakan. Keduanya sama-sama menggunakan huruf kapital. Penulisan "teh wangi" pada visual kemasan teh Cap Soklat yang dicetak dnegan huruf kapital dan berwarna hijau memiliki kriteria huruf sans serif. Huruf sans serif mempunyai ciri sebagai berikut (1) garis melengkung berbentuk square/persegi, (2) terdapat perbedaan kontras yang halus, dan (3) bentuk mendekati penekanan ke arah garis vertikal.

2. Cap Buah Soklat

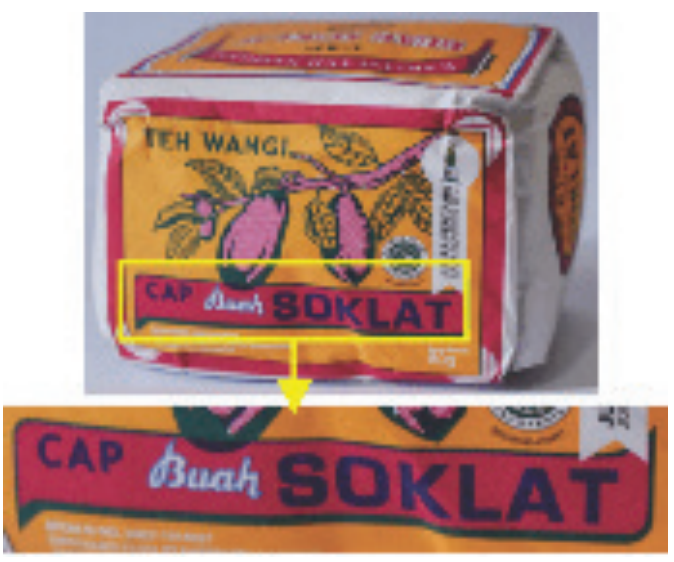

Gambar 34. Tipografi "cap buah soklat" dalam visual kemasan teh Cap Soklat. (Sumber: Dokumentasi Ayu Latifah) 
Pada kalimat "Cap Buah Soklat" yang digambarkan ditulis diatas pita merah, ketiganya memiliki karakter huruf yang berbeda. Pada kata "Cap" merupakan kategori huruf sans serif dan terletak di sisi atas kanan pita merah. Sementara huruf "Buah" ditulis menggunakan gaya huruf script atau menyerupai tulisan tangan yang menampilkan kesan dinamis, anggun dan lembut. Sementara pada tulisan "Soklat" merupakan kategori huruf sans serif dengan ukuran yang paling besar dari ketiga kata tersebut.

\section{Kartini Teh Nasional}

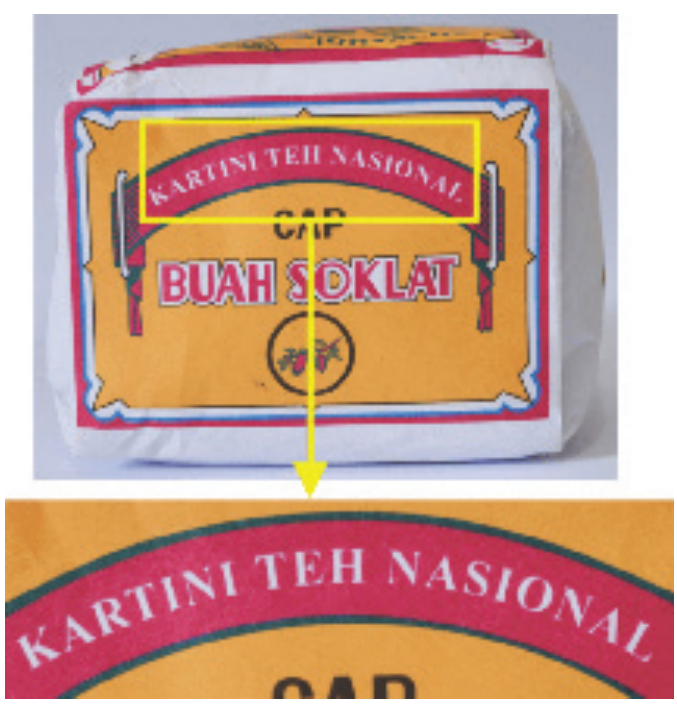

Gambar 35. Tipografi "Kartini Teh Nasional” dalam visual kemasan Teh Cap Soklat.

Kalimat "Kartini Teh Nasional" merujuk pada nama perusahaan yang memproduksi teh tersebut yaitu PT. Kartini Teh Nasional. Merupakan kategori huruf serif dan dicetak menggunakan huruf Times New Roman yang bentuknya mengikuti lengkungan pita sebagai latar belakang dari tulisan tersebut. Memberikan kesan tegas, formal dan mewakili dari citra perusahaan itu sendiri.

4. Tipografi dalam teh Cap Soklat menunjukkan gaya desain yang digunakan dan dipengaruhi pada masa itu, yang paling kentara adalah penulisan soklat berikut ini

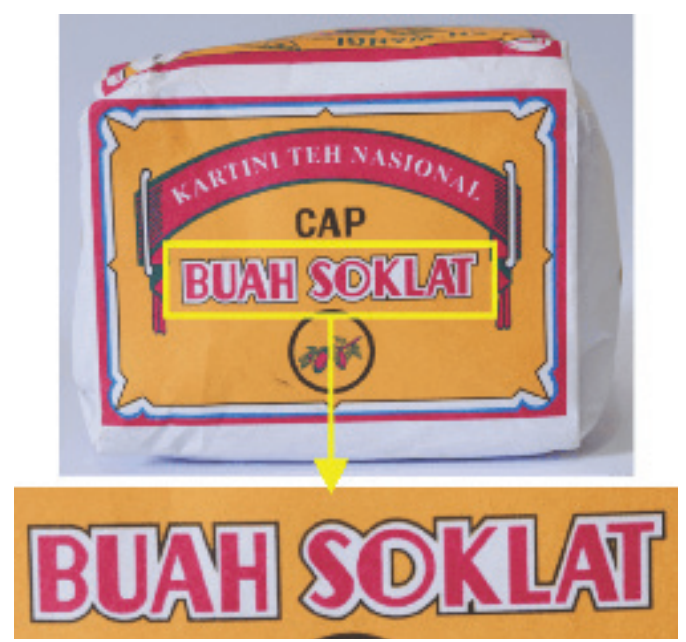

Gambar 36. Tipografi "Buah Soklat"dalam visual

kemasan Teh Cap Soklat.

(Sumber: Dokumentasi Ayu Latifah)

Penggunaan tipografi dalam penulisan "buah soklat" mewakili karakter dari gaya desain Art Deco. Karakteristik dari Art Deco adalah terdapat bentukbentuk geometris, bold kurva, strong vertical lines, efek airbrush dan gradasi warna, juga menekankan penggunaan ilustrasi dan representasi dari bangunan atau benda sehari-hari. Budidaya kakao dan budaya cokelat berkembang pesat di Indonesia pada abad 19 dan 20. Dilihat dari iklan-iklan zaman dulu, cokelat lebih identik sebagai minuman daripada camilan seperti sekarang. Cokelat juga menjadi simbol dari status sosial. Hal ini terlihat dari iklan dari merek cokelat produksi Amsterdam 'Tjoklat'. Tampak seorang perempuan Melayu berkemben dan bersanggul duduk bersimpuh mempersembahkan sebakul buah kakao. Iklan tersebut disebutkan Faldy membuktikkan bahwa cokelat menjadi simbol status sosial. Pada masa kolonial juga, Indonesia pernah menjadi salah pemasok kakao terbesar di dunia. Dari merek Tjoklat saja, ada 63 juta cokelat batangan diproduksi per tahun. Nama merek 'Tjoklat' diambil dari Bahasa Melayu.

Pasca kemerdekaan, aneka merek cokelat lokal berkembang di Tanah Air. Cokelat lantas tak hanya dapat dinikmati 
kaum elit, tetapi semua kalangan masyarakat hingga saat ini. Tentunya dengan berbagai varian harga yang sesuai dengan komposisi cokelat. Selera cokelat juga berganti bentuk sejak era tersebut, dari yang tadinya cairan diminum kini menjadi camilan yang dikunyah. Sampai saat ini Indonesia menjadi pemasok biji kakao ke tiga terbesar di dunia dan terkenal dengan kualitas kakao unggulan. Namun konsumsi cokelat masyarakat Indonesia terbilang rendah, hanya 500 gram per kapita pertahunnya. Budidaya kakao kurang diminati petani Indonesia karena dilihat kurang menguntungkan, padahal ada manfaat kesehatan dalam konsumsi cokelat dan tentunya dampak ekonomi yang diperoleh dari penjualan coklat.

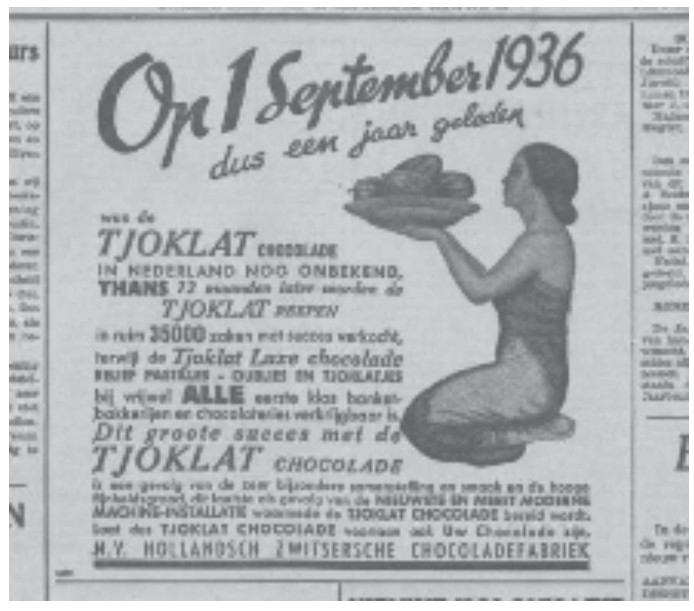

Gambar 37. Advertentie voor Tjoklat chocolade uit het: Nieuw Israelietisch weekblad van 10 september 1937. Bron: Historische kranten.

(Sumber: https://geheugenvanoost.amsterdam)

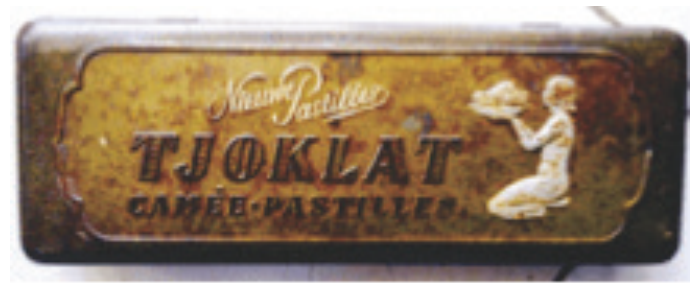

Gambar 38. Kaleng Tjoklat Camee Pastilles Chocolates Amsterdam Holland 1960's (Tjoklat Camee Pastilles Tin Box)

(Sumber: https://rusthour2015.blogspot.com)

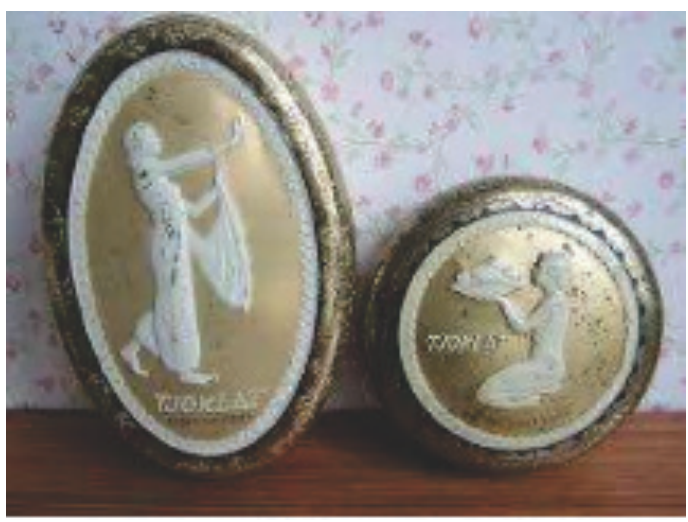

Gambar 39. Vintage Tjoklat Camée Pastilles Tins Containers Storage Oval Round Metal Canisters Gold White Lady Dutch Chocolates Amsterdam Holland 1960's

(Sumber: https://hautejuice.wordpress.com)

Kaleng tjoklat antik buatan Belanda merek "Tjoklat Camee Pastilles" dengan lambang yang sangat kental aroma Hindia Belanda-nya. Produk ini beredar dalam 3 varian bentuk kaleng, yakni bentuk bundar, elips. Kaleng yang berbentuk elips bergambar perempuan penari Jawa, sedangkan yang bundar dan yang persegi bergambar perempuan duduk bersimpuh sambil membawa nampan yang menyajikan buah kakao. Hal tersebut menunjukkan adanya kelas sosial dilihat dari penggunaan subjek perempuan yang duduk bersimpuh sambil membawa nampan yang menyajikan buah kakao untuk disajikan kepada seseorang yang jelas mempunyai kelas sosial satu tingkat diatasnya. Sebagaimana akanan dapat menjadi simbol status sosial seseorang lantaran dapat menggambarkan keadaan ekonomi orang tersebut dilihat dari jenis makanan yang akan disantap untuk dirinya sendiri maupun keluarganya.

\section{Kesimpulan}

Dari hasil penelitian yang ada pada bab sebelumnya maka terdapat beberapa aspek yang didapati yaitu yang pertama ialah aspek material dan yang kedua aspek formal. Aspek material berkaitan dengan desain dan karakter desain yang ada pada label kemasan teh Cap Nyapu dan teh Cap Soklat. Sedangkan dari segi formal ialah bagaimana konten atau maknaa dalam visual 
kemasan teh Cap Nyapu dan teh Cap Soklat itu ditampilkan. Berdasarkan prinsip-prinsip desain pada kedua sampel terdapat beberapa kemiripan diantaranya jenis tipografi dan ilustrasi kedua produk tersebut. Tipografi pada kedua sampel banyak menggunakan jenis script atau menyerupai tulisan tangan yang mengesankan keanggunan dan informal. Ilustrasi yang terdapat dalam kemasan teh Cap Nyapu dan teh Cap Soklat banyak menggunakan teknik manual, namun dengan gaya yang berbeda.

Dalam visual kemasan teh Cap Nyapu, menggunakan dominasi perpaduan warna merah, orange, kuning dan biru. Warna merah, orange dan kuning merupakan kategori warna panas, yang mengesankan citra visual citra visual yang hangat. Sementara warna biru merupakan kategori warna dingin. Warna dingin mempunyai kesan sejuk, damai, alami dan bersahaja. Adapun dalam visual kemasan teh Cap Nyapu dominasi warna panas dan dingin ini terlihat seimbang dan harmonis, dengan adanya ilustrasi yang didominasi warna panas namun diseimbangkan dengan background bermotif yang berwarna biru.

Penggunaan frame berwarna kuning dengan bentuk lingkaran yang mengelilingi ilustrasi dalam visual kemasan teh Cap nyapu dan tipografi berupa tulisan yang ditulis latin pada merk produk menonjolkan gaya Victorian, seperti yang disebutkan memiliki ciri-ciri sebagai berikut (1) Ilustrasi secara realisme dan sentimental serta mengutamakan keindahan, yang digambarkan melalui pemandangan alam sebagai latar belakang dalam ilustrasi visual kemasan teh Cap Nyapu (2) Penggambaran karakter perempuan yang berbadan subur, yang jelas terlihat dalam objek orang yang menyapu dalam ilustrasi pada kemasan teh Cap Nyapu (3) Framing berupa ornamen-ornamen, dalam hal ini frame berupa lingkaran berwarna kuning dengan outline hitam. (4) Banyak ditemui karya-karya yang sifatnya simetris, yang terlihat dalam ilustrasi teras dengan outline biru yang simetris dan ilustrasi pagar berwarna merah (5) Tipografi dengan menggunakan fonts jenis script mendominasi visual kemasan teh cap Nyapu (5) Penggunaan warna warna merah, kuning, jingga dan biru menerapkan realitas dalam ilustrasi tersebut. Misalnya penggunaan warna biru dalam ilustrasi gunung dan warna hijau untuk ilustrasi sawah dan rimbunnya pohon.

Ilustrasi dalam visual kemasan teh Cap Nyapu, lekat dengan kebudayan Jawa dilihat dari penggunaan nama merk itu sendiri, kebaya merah dan jarik bermotif batik parang yang digunakan oleh perempuan yang tengah menyapu, serta penggunaan kata 'perusahaan teh Widodo Pekalongan, yang mana Pekalongan terletak di Jawa Tengah. Penggunaan gabah yang diikat dan busana yang dikenakan perempuan yang tengah menyapu dapat menunjukkan tren kala itu, dimana perempuan masih mengenakan kebaya dan batik dalam kehidupan sehari-hari yaitu masa kolonialisme. Dapat disimpulkan perempuan dalam visual kemasan teh Cap Nyapu merupakan golongan wong cilik, dikarenakan perempuan pada visual kemasan teh Cap Nyapu tidak mengenakan aksesoris atau perhiasan satupun, berbeda dengan golongan priyai/ningrat saat itu yang mengenakan kebaya dengan kain yang lebih tebal dan mengenakan perhiasan dan aksesoris yang merepresentasikan kelas sosialnya.

Visual kemasan teh Cap Soklat menggunakan dominasi perpaduan warna kuning dan merah dilengkapi dengan warna lainnya yaitu; hijau, biru dan merah muda sebagai warna turunannya. Warna kuning dan merah merupakan kategori warna panas. Seperti yang telah disebutkan sebelumnya, warna panas mengesankan citra visual citra visual yang hangat yang melambangkan api dan musim kemarau. Sedangkan warna hijau merupakan kategori warna dingin. Warna dingin mempunyai kesan sejuk, damai, alami dan bersahaja. Visual kemasan teh Cap Soklat didominasi oleh warna panas, terlihat dari penggunaan frame simetris berwarna merah serta background berwarna kuning. Lantaran warna hijau dan biru tidak lebih banyak penggunaannya dibandingkan dengan warna kuning dan merah sebagai warna panas. Penggunaan tipografi bergaya simetris yang terdapat dalam penulisan 'teh' dan'buah soklat' visual kemasan teh Cap Soklat menunjukkan gaya Art Deco, sebagaimana ciri desain grafis bergaya Art Deco yaitu menampilkan warnawarna yang cerah dan hidup diantara motifmotif floral, figuratif dan geometris, yang terlihat 
pada penggunaan warna merah dan kuning dan tipografi yang geometris.

Sementara dalam visual kemasan teh Cap Soklat menampilkan ilustrasi buah kakao. Tipografi dan gaya ilustasi yang digunakan menunjukkan bahwa gaya Art Deco (1918 1939) menjadi pengaruh gaya desain grafis pada masa ttersebut. Penggunaan ilustrasi buah kakao dalam visual kemasan produk teh, dalam hal ini teh Cap Soklat, merupakan hal yang anomali, lantaran alih-alih menggunakan ilustrasi tanaman teh justru menggunakan ilustrasi buah kakao yang tidak ada sangkut pautnya dengan bahan produksi teh Cap Soklat itu sendiri. Namun dari latar belakang sosio-historis yang ada, kedua tanaman tersebut yaitu teh dan kakao, keduanya merupakan tanaman yang masuk dalam kategori tanaman yang ditanam dalam sistem cuulturstelsel lantaran keduanya sama-sama dibawa masuk dan dikembangkan dalam wilayah VOC atau Perusahaan Hindia Timur Belanda.

\section{Saran}

Saran dari penulis ialah diharapkan adanya penelitian serupa mengenai visual kemasan teh tubruk lokal yang mengambil sampel teh lokal lainnya sebagai sarana apresiasi terhadap karya desain dan produk lokal, dengan pendekatan sosio-historis atau latar belakang lainnya. Sehingga dapat menjadi wacana bahwa sejarah nasional berpengaruh besar dan membentuk kebudayaan saat ini, pun kaitannya terhadap teknologi dan khususnya ilmu Desain Komunikasi Visual. Penelitian ini masih memiliki banyak kekurangan terkait penelitian tugas akhir ini, seperti jangkauan yang kurang luas atau pembahasan yang kurang spesifik sehingga penulis mengharapkan semoga kajian tugas akhir ini dapat menjadi sumbangan pengetahuan untuk kepentingan praktik maupun penelitian desain.

\section{Daftar Pustaka}

\section{Buku}

Julianti, Sri. (2014). The Art of Packaging. Jakarta: PT. Gramedia Pustaka Utama.

Kartodirdjo, Sartono. (1999). Pengantar Sejarah Indonesia Baru: Sejarah Pergerakan Nasional Dari Kolonialisme Sampai Nasionalisme. Jakarta: PT. Gramedia Pustaka Utama.

Klimchuk, Marianne Rosner dan Sandra, A. Krasovec. (2006). Desain Kemasan Perencanaan Merk Produk yang Berhasil Mulai dari Konsep sampai Penjualan. Jakarta: Erlangga.

Koentjaraningrat. (2010). Manusia dan Kebudayaan di Indonesia. Jakarta: Djambatan.

Sachari, Agus.( 2002). Sosiologi Desain. Bandung: Penerbit ITB.

Sachari, Agus. (2007). Budaya Visual Indonesia. Jakarta: Erlangga.

Sunarto, Wagiono.(2013). Gaya Desain Tinjauan Sejarah. Jakarta: PascaIKJ.

Wirya, Iwan. (1999). Kemasan yang Menjual. Jakarta: PT. Gramedia Pustaka Utama

\section{Webtografi}

https://kumparan.com/@kumparanstyle/ mengenal-jarik-salah-satu-jenis-kain-indonesiadari-tanah-jawa-1534589383979514824 Mengenal Jarik, Salah Satu Jenis Kain Indonesia dari Tanah Jawa. diakses pada 28 Mei 2019, pukul 05:52 WIB.

Motif Batik Indonesia https://infobatik.id/motifbatik-parang-ini-makna-dan-jenisnya/ diakses pada 29 Mei 2019. Pukul 08:08 WIB.

http://www.food-info.net/id/products/tea/ history.htm

https://graphicmama.com/blog/types-ofillustration/

http://www.wacana.co/2016/09/gaya-indiesdesain-grafis-indonesia-tempo-doeloel

http://studiokemasan.blogspot.com/2013/06/ makna-dalam-sebuah-kemasan.html

Tafoya, Renee Claire. Graphic Design History

https://visualartsdepartment.wordpress.com/ deco/ diakses pada 25 Mei 2018 pukul 07:28 WIB 